\title{
O GÊNERO OMBUDSMAN NA PERSPECTIVA DA ANÁLISE CRÍTICA DO DISCURSO
}

\author{
THE GENRE OMBUDSMAN UNDER THE PERSPECTIVE \\ OF CRITICAL DISCOURSE ANALYSIS
}

\author{
Rita de Cassia Fernandes Signor \\ Mestranda do Programa de Pós-graduação em Linguística, -UFSC \\ Vidomar Silva Filho \\ Doutorando do Programa de Pós-graduação em Linguística - UFSC
}

\section{Resumo}

Mediante análise de 18 colunas dos ombudsman Carlos Eduardo Lins da Silva (Folha de S. Paulo) e Rita Célia Faheina (O Povo), investigamos como o gênero ombudsman se constitui em meio à mobilização de diferentes vozes. Nosso suporte teórico é a Análise Crítica do Discurso e, mais especificamente, o modelo de análise de Fairclough (1989). Esse autor sugere que os dados sejam investigados por meio de três dimensões: como texto, como prática discursiva e como prática social. Para contemplar essas dimensões do enunciado, analisamos: a) na dimensão do texto, os participantes dos processos verbais expressos por verbos dicendi; b) na dimensão da prática discursiva, as estratégias de construção simbólica mobilizadas no texto; c) na dimensão da prática social, as relações sociais estabelecidas entre o ombudsman e seu público, a identidade social que o ombudsman constrói para si e os modos de operação da ideologia para manutenção da hegemonia do jornal. Os resultam sugerem que o gênero ombudsman pode compreender formas bastante diversas de interação. Silva cria a identidade de um ombudsman que trata de questões mais gerais do jornalismo, servindo como "consciência" do jornal. Já Faheina constitui-se como representante do leitor. Esses dois modos de operação do gênero podem estar relacionados ao leitor visado de cada jornal. Lins parece supor um leitor mais intelectualizado, enquanto Faheina parece prever leitores mais preocupados com questões cotidianas. As colunas têm em comum o fato de constituírem espaços para leitores exporem suas críticas, criando a impressão de que o monologismo e autoritarismo, inerentes ao jornalismo, estão relativizados. No entanto, a crítica possível não atinge o cerne do fazer jornalístico. Assim, pode ser largamente ilusória a pluralidade de vozes no espaço discursivo gerado pela coluna.

Palavras-chave: Gêneros do discurso. Análise Crítica do Discurso. Ombudsman.

\begin{abstract}
By means of an analysis of 18 columns of the ombudsmans Carlos Eduardo Lins da Silva (Folha de S. Paulo) and Rita Célia Faheina (O Povo), we investigate how the genre ombudsman is constituted by means of the mobilization of different voices. Our theoretic basis is Critical Discourse Analysis and, specifically, the model of analysis proposed by Fairclough (1989). This author suggests that the data are investigated according to three dimensions: as text, as discursive practice, and as social practice. In order to comprise those dimensions of enunciation, we analyze: a) within the text
\end{abstract}


dimension, the participants of verbal processes expressed by verba dicendi; $b$ ) within the dimension of discursive practice, the strategies of symbolic construction mobilized in the text; c) within the dimension of social practice, the social relations established between the ombudsman and her/his readers, the social identity that the ombudsman builds up for her/himself, and the modes of operation of ideology for the maintenance of the hegemony of the newspaper. The results suggest that the genre ombudsman may encompass rather diverse forms of interaction. Silva creates the identity of an ombudsman who deals with the broader issues of journalism, working as a "conscience" for the newspaper. Faheina, on the other hand, poses herself as a representative of the readers. These two modes of operation of the genre ombudsman may be related to the intended reader of each newspaper. Lins seems to presuppose a more intellectualized reader, while Faheina seems to assume her readers to be more concerned with daily-life issues. Both ombudsman columns share the characteristic of constituting spaces for the readers to express their criticisms, creating the impression that the monologism and authoritarianism, which characterize journalism, are diminished. However, the possible criticism does not reach the core of journalistic activity. Thus, the plurality of voices within the discursive space generated by the column may be largely illusory.

Keywords: Discourse genres. Critical discourse analysis. Ombudsman.

\section{INTRODUÇÃO}

A função de ombudsman foi criada na Suécia, no século XVI. Contratado pelo rei, o ombudsman era um funcionário cujo trabalho consistia em controlar as atividades dos juízes. Mais tarde, em 1809, o parlamento sueco criou oficialmente o cargo de ombudsman, como um representante do povo junto aos órgãos do estado (SANTOS, s/d). Na imprensa, o cargo de ombudsman apareceu pela primeira vez nos EUA, nos anos 60. No Brasil, o primeiro jornal a contratar um ombudsman foi a Folha de $S$. Paulo, que mantém a função desde 1989, sempre exercida por um jornalista.

A atividade do ombudsman cumpre dupla função discursiva. Ao mesmo tempo em que é incumbido, como jornalista, de fazer uma crítica ao jornal, ele também busca constituir, com sua coluna, um canal para os leitores expressarem suas opiniões e críticas e também para que os colegas jornalistas possam defender-se de eventuais críticas, oferecendo justificativas e explicações. Portanto, a coluna de ombudsman deve, idealmente, representar um espaço de pluralidade de opiniões.

Neste trabalho, mediante a análise das colunas de ombudsman dos jornais Folha de $S$. Paulo e O Povo, publicadas nos meses de agosto e setembro de 2009, buscamos investigar como esse espaço de pluralidade se constitui mediante a mobilização de diferentes vozes. Examinamos também como o ombudsman constrói, através de sua coluna, uma identidade binária de jornalista, representante do jornal, e, ao mesmo tempo, representante dos leitores junto ao jornal. Reconhecendo que essa dupla identidade implica um jogo de tensões entre uma força hegemônica - o jornal - e um conjunto de dominados, representado pelos leitores, buscamos também investigar como o discurso do ombudsman, manifesto nas colunas, reflete essa tensão. 
Adotamos como referencial teórico para análise a Análise Crítica do Discurso (ACD) e, mais especificamente, o modelo de análise proposto por Norman Fairclough. De acordo com Meurer (2005), Fairclough propõe que os enunciados sejam analisados segundo três dimensões: como texto, como prática discursiva e como prática social. Cada uma dessas dimensões corresponde, respectivamente, a uma modalidade de procedimento analítico: descrição, interpretação e explicação. Na primeira modalidade de análise, do enunciado como texto, faz-se uma descrição dos elementos linguísticos (léxico, sintaxe, coesão, etc.). Na segunda dimensão de análise, que enfoca o enunciado como prática discursiva, busca-se interpretá-lo em termos de sua produção e de sua recepção e interpretação pelos interlocutores. Nessa dimensão de análise, contemplam-se fenômenos como intertextualidade e interdiscursividade, e, como destaca Meurer (2006, p. 95), o texto é situado "em relação a práticas discursivas que o definem como gênero e como discurso", entretanto, como se verá a seguir, Fairclough não chega a aprofundar teoricamente a questão do gênero. Já na terceira dimensão de análise, sendo o enunciado abordado como prática social, procura-se explicar como o texto materializa determinadas formações ideológicas e formas de hegemonia. Essas três dimensões de análise são assim representadas por Meurer (2005):

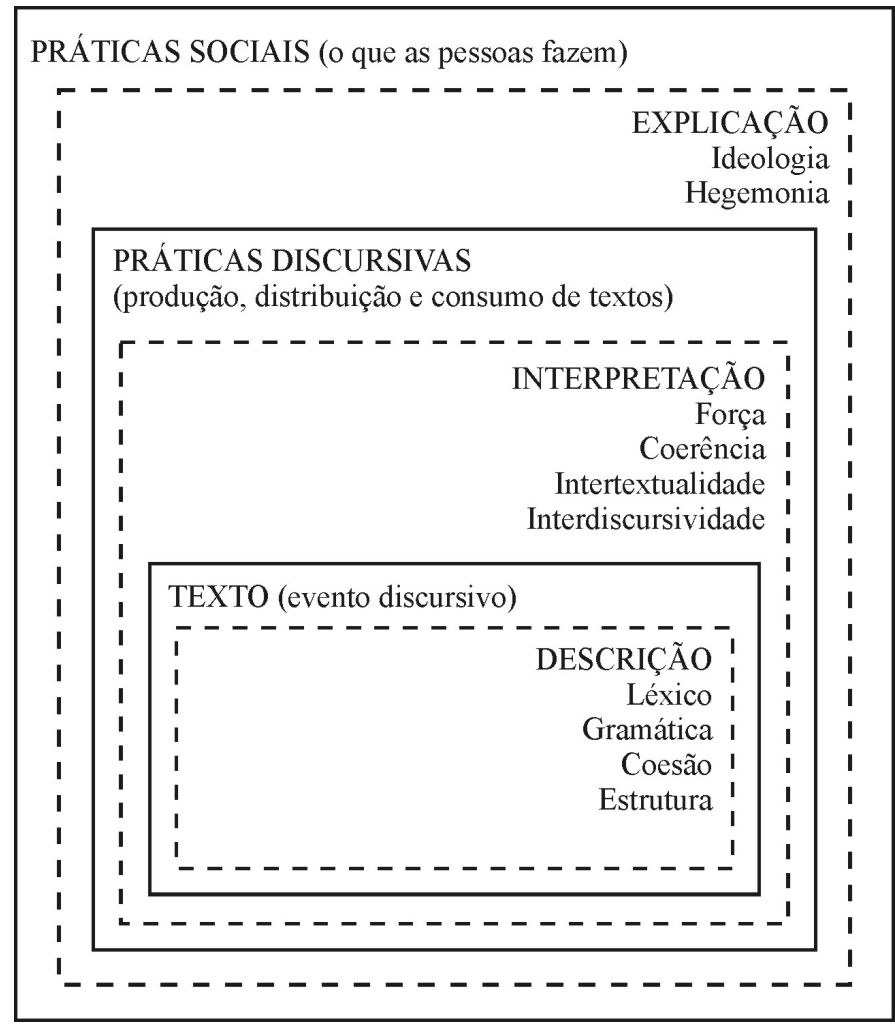

FIGURA 1. Representação esquemática do modelo de análise de Fairclough (apud MEURER, 2005, p. 95)

A fim de contemplar essas três dimensões de análise, o presente estudo investiga: 
a) na dimensão do enunciado como texto, os participantes ${ }^{1}$ dos processos verbais expressos por verbos dicendi ${ }^{2}$;

b) na dimensão do enunciado como prática discursiva, as estratégias de construção simbólica mobilizadas no texto;

c) na dimensão do enunciado como prática social, quais relações sociais são estabelecidas entre o ombudsman e seu público, qual identidade social o ombudsman constrói para si através de sua coluna e os modos de operação da ideologia para manutenção da hegemonia do jornal.

\section{REFERENCIAL TEÓRICO}

Esta seção trata do aparato teórico da $\mathrm{ACD}$. A primeira subseção discorre sobre a constituição da ACD como uma corrente epistemológica. As subseções seguintes trazem as noções de gênero e de discurso da teoria. Esta última se divide em: discurso como prática social, discurso e poder, discurso e mudança social, discurso e ideologia. Por fim, é focalizada a face linguística da $\mathrm{ACD}$, onde é abordada a recontextualização da Linguística Sistêmico-Funcional (LSF) em Fairclough.

\subsection{A constituição da ACD}

A ACD se consolidou como disciplina em janeiro de 1991, em um simpósio na cidade de Amsterdã, quando se reuniram Teun van Dijk, Norman Fairclough, Gunter Kress, Theo van Leeuwen e Ruth Wodak. Norman Fairclough, o maior expoente da ACD, começou a fundar uma análise crítica da linguagem já em 1989. Neste ano, publica a obra Language and Power, em que sinaliza questões que remetem para a conscientização das relações assimétricas de poder (RESENDE E RAMALHO, 2006). O próprio termo Análise Crítica do Discurso foi cunhado, conforme Magalhães (2005), por Fairclough em um artigo publicado no Journal of Pragmatics.

A ACD se baseia em uma concepção de linguagem como inerente à vida social dialeticamente inter-relacionada a outros elementos sociais (FAIRCLOUGH, 2003a). É uma proposta que constitui amplo aparato teórico e metodológico para o tratamento de questões ligadas ao discurso na prática social. Para os analistas do discurso da linha crítica, o que é relevante é a investigação do funcionamento do sistema linguístico na construção das relações sociais; na estruturação e contestação de hegemonias no discurso. Resende e Ramalho (2006) afirmam que o conhecimento de uma gramática funcionalista é fundamental para que se entenda como as estruturas linguísticas são utilizadas como forma de ação sobre as pessoas e sobre o mundo; entretanto, reconhecem que existe a necessidade de equilíbrio entre o sistema da língua e sua função nos estudos linguísticos, já que o enfoque em apenas um dos aspectos poderia reduzir a linguagem a uma ferramenta social ou a uma ferramenta formal. A busca por esse equilíbrio é o que move os estudos amparados na ACD.

\footnotetext{
${ }^{1} \mathrm{Na}$ Linguística Sistêmico-Funcional, essas participantes são chamados 'dizentes', termo que será adotado neste trabalho.

${ }^{2}$ Verbos dicendi ou verbos de dizer são os que expressam comportamentos de linguagem verbal, como dizer, exclamar, perguntar, negar, retrucar etc.
} 


\subsection{A noção de gênero na ACD}

Em Fairclough, não é possível encontrar uma noção de gêneros totalmente delineada. Para o autor, gêneros específicos estão vinculados às práticas sociais a eles relacionados. Dessa forma, mudanças nessas práticas refletem em transformações nos gêneros, ou seja, nas formas de ação e interação. Diz ainda que essa mudança nos gêneros ocorre pela recombinação de gêneros preexistentes, e que alguns gêneros são mais estáveis do que outros, alguns possuem padrões de composição mais rígidos, enquanto outros são mais flexíveis.

Fairclough (2003a) fala em pré-gêneros e em gêneros situados. Os primeiros são categorias abstratas que participam da composição dos situados. Exemplos de prégêneros são as narrativas, descrições e argumentações. Assim, o pré-gênero narrativa é alçado na produção de contos, novelas, filmes etc. Gêneros situados são categorias concretas, utilizados na definição de práticas particulares como a reportagem, o editorial e a crônica, por exemplo. Importante comentar que um gênero situado engloba vários pré-gêneros (no entanto, um pré-gênero será o predominante). Desse modo, uma reportagem é constituída de narração, argumentação, descrição e outros pré-gêneros.

Fairclough (2003a) salienta que não há uma lista de gêneros (são incontáveis, pois inúmeros) e que são poucos os nomes estáveis para gêneros, e que, por isso, a nomeação é pouco significante na análise. $\mathrm{O}$ importante é que o gênero seja aceito como uma forma de linguagem pertencente a esferas particulares. $\mathrm{O}$ autor diz que não é possível determinar aspectos composicionais rigorosos para gêneros, considerando que estes não são constituídos por regras estáticas, tampouco por padrões imutáveis. Em 1999, Fairclough e Chouliaraki dizem que um gênero deve ser entendido como "a faceta regulatória do discurso", já que se perfaz em um mecanismo regulatório, que controla o que pode ser dito e de que forma (em que ordem) pode ser dito. No entanto, pela dialética entre estrutura e ação, essa regulação pode ser questionada e, desse modo, a transformação discursiva aparece como uma faceta de lutas hegemônicas.

\subsection{Influências recebidas pela ACD}

A base epistemológica da ACD surge como resposta às críticas que Fairclough realiza em torno de várias abordagens teóricas que se propõem a estudar a linguagem, dentre essas estão a linguística tradicional, a sociolinguística, a pragmática, a análise da conversação, a linguística crítica de Fowler, a abordagem de Pêucheux acerca do discurso, entre outras (MEURER, 2005). Para Fairclough (1989), tais perspectivas relativizam as conexões existentes entre o discurso e as relações de poder (produção, mudança e manutenção dessas relações). Da mesma forma que critica, a ACD assimila extratos positivos de todas essas vertentes. Meurer (2005) afirma que a noção de linguagem como ação, aceita pela $\mathrm{ACD}$, vem de influências recebidas da pragmática. De Pêuchex, a ACD incorpora a visão de linguagem enquanto materialização da ideologia. Da linguística crítica, absorve a associação entre a linguística sistêmico funcional (LSF) e uma teoria social de linguagem. A ACD também recebe a noção de 
discurso de Foucault e assimila aspectos do dialogismo ${ }^{3}$ proposto por Bakhtin. Sendo uma abordagem transdisciplinar, a ACD operacionaliza e transforma tais teorias em favor de uma abordagem sociossemiótica.

Bakhtin foi fundador da primeira teoria semiótica da ideologia e a ACD incorpora o dialogismo proposto pelo autor, como já mencionamos. Na concepção faircloughiana, o termo texto está atrelado à noção de texto-enunciado de Bakhtin; assim, cada texto (visto como um enunciado) representa um elo na comunicação discursiva. $O$ enunciado/texto nada mais é do que uma resposta a outros enunciados que já foram produzidos em outras situações interacionais; ou seja, o ato de fala é atravessado por outros discursos: "baseia-se neles, polemiza com eles, simplesmente os pressupõe já conhecidos do ouvinte" (BAKHTIN, 2003, p.272). Do mesmo modo que o texto representa uma resposta, ele suscita outra, tornando o processo discursivo vinculado a uma cadeia discursiva ininterrupta. A ACD também se preocupa com as condições de produção dos textos (de onde se fala, para quem se fala, com que intenção, de que lugar social, a visão do interlocutor, as estratégias usadas durante a comunicação, circunstâncias de poder e ideologia etc.).

A noção de linguagem como forma de luta hegemônica, por sua vez, é atrelada aos trabalhos desenvolvidos por Foucault. Fairclough (2001a) vê no autor uma das mais fortes contribuições para a formação de uma Teoria Social do Discurso. "Para a ACD, importam dentre as discussões foucaultianas, sobretudo, o aspecto constitutivo do discurso, a interdependência das práticas discursivas, a natureza discursiva do poder, a natureza política do discurso e a natureza política da mudança social" (RESENDE E RAMALHO, 2006, p.18). Foucault (2003) impõe a face constitutiva do discurso; o autor diz que para que se analise o discurso se faz necessário especificar as formações discursivas interdependentes.

\subsection{O discurso na ACD}

Para Fairclough o termo discurso carrega uma ambiguidade saudável. Isto significa que discurso é um termo polissêmico. Por um lado apresenta um significado que se atrela à ideologia; por outro lado, pode ser encarado como uma ocorrência de uso da linguagem, equiparando-se ao termo texto. Assim, cada fenômeno discursivo pode ser visto de várias formas: como um texto, como a manifestação do discurso e como prática social (FAIRCLOUGH, 1992 apud MEURER, 2005).

\subsubsection{O discurso como prática social}

Fairclough (1989, p. 20) começa defendendo sua tese em favor do discurso como prática social através de uma crítica ao trabalho de Saussure. Relata a oposição langue e parole proposta pelo autor e refuta a ideia de que a fala seja um fato determinado por

\footnotetext{
${ }^{3}$ O dialogismo é uma das teses centrais de Bakhtin. A palavra diálogo é entendida, nos estudos do Círculo de Bakhtin, como reação do eu ao outro, como tensão de valores, crenças, atitudes, forças sociais. "A essa perspectiva, interessa não a palavra passiva e solitária, mas a palavra na atuação complexa e heterogênea dos sujeitos sociais, vinculada a situações, a falas passadas e antecipadas" (MARCHEZAN, 2006, p.123).
} 
escolhas puramente individuais. Do mesmo modo, não aceita a noção de que a língua seja homogênea. Nos termos do autor:

Language use (parole) is, as Saussure was aware, characterized by extensive linguistic variation, and it is the account of this variation given by modern sociolinguistics which has done most to undermine the Saussurean concept of parole. Sociolinguistcs has shown that this variation is not, as saussure thougt, a product of individul choice, but a product of social differentiation - language varies according to the social identities of people in interactions, their socially defined proposes, social setting, and so on. So saussure's individualisttic notion of parole is unsatisfactory, and in preferring the tern discourse I am first of all committing myself to the view that language use is socially determined.

But what about langue? Saussure understood langue as something unitary and homogeneous throughout a society. But is there such a thing as 'a language' in this unitary and homogeneous sense? ${ }^{4}$

Fairclough diz que Saussure parte do princípio de que a língua, enquanto entidade homogênea, é igualmente acessível a todos de uma mesma comunidade linguística, mas para o Fairclough tal acesso é desigual. Ao rejeitar as noções saussurianas acerca da linguagem, Fairclough centra-se na noção de discurso, tomando a língua como socialmente determinada, caracterizada pela diversidade e pela luta de poder, sendo a homogeneidade vista como uma forma de alcance de um padrão posto a priori por aqueles que detêm esse poder.

Ao considerar a linguagem como uma prática social, o autor relata três implicações referentes a esse pensamento. Primeiramente, significa que a linguagem é parte da sociedade e não algo externo a ela. Depois, a linguagem é vista como um processo social. E, por fim, a linguagem é um processo condicionado socialmente por parâmetros não-linguísticos que fazem parte da sociedade.

Considerar a linguagem como parte da sociedade requer uma crítica aos que estudam a relação entre linguagem e sociedade como se estas fossem entidades independentes. Fairclough (1989) diz que não existe uma relação externa entre língua e sociedade, mas uma relação interna e dialética. A linguagem é parte da sociedade; fenômenos linguísticos são fenômenos sociais, e fenômenos sociais são (em parte) fenômenos linguísticos. Dizer que fenômenos linguísticos são sociais implica a aceitação de que indivíduos falam, escrevem, leem e ouvem por meio de ações socialmente

\footnotetext{
${ }^{4}$ O uso da linguagem (parole) é, como Saussure sabia, caracterizado por extensa variação linguística, e é a explicação dessa variação oferecida pela moderna sociolinguística que mais tem feito para minar o conceito saussureano de parole. A sociolinguística mostrou que essa variação não é, como pensava Saussure, um produto de escolhas individuais, mas produto de diferenciação social - a língua varia de acordo com as identidades sociais das pessoas em interações, seus propósitos socialmente definidos, entorno social, e assim por diante. Assim a noção saussureana individualista de parole é insatisfatória, e, ao preferir o termo discurso, eu estou, antes de mais nada, me aliando à visão de que o uso da linguagem é socialmente determinado.

Mas e quanto à langue? Saussure compreendia a langue como algo unitário e homogêneo através da sociedade. Mas existe algo assim como uma 'língua', nesse sentido unitário e homogêneo?(Tradução nossa)
} 
determinadas. Compreender que fenômenos sociais são linguísticos, por outro lado, significa entender que a linguagem se dá em um contexto eminentemente social; não como mero reflexo de processos ou práticas sociais, mas como parte integrante dessas práticas. Entretanto, o autor alega que a relação entre linguagem e sociedade não se dá de forma simétrica.

A segunda implicação, que vê a língua como um processo social, remete à noção de texto. Fairclough coloca que o texto pode ser encarado como um produto de um processo interacional (discursivo); considera texto parte integrante do momento da interação. Para o autor, o processo interacional que resulta no produto textual emana algo que engloba as condições em que o texto foi produzido. Salienta ainda que em termos de análise, tais condições são apenas um dos aspectos considerados. A análise requer que se investiguem os processos de produção e interpretação pessoais, os quais incluem conhecimentos acerca da linguagem, representações de mundo, crenças, valores, suposições e outras.

A terceira implicação a que o autor se refere (as questões não-linguísticas), por sua vez, nada mais é do que os aspectos cognitivos que movem as ações individuais socialmente motivadas. No entanto, não é só a natureza desses recursos cognitivos que é socialmente determinada, mas também as condições de sua utilização - por exemplo, diferentes estratégias cognitivas são acionadas quando alguém está lendo um poema ou quando está lendo um anúncio em uma revista, por exemplo. É importante ter em conta essas diferenças quando se analisa o discurso em uma perspectiva crítica.

Dessa forma, então, discurso, para Fairclough (1989), envolve as condições sociais que podem ser especificadas como condições sociais de produção e condições sociais de interpretação. Tais condições dizem respeito a três níveis de organização social: o nível da situação social, ou o meio social imediato no qual o discurso ocorre; o nível da instituição social, que constitui uma matriz mais ampla para o discurso; e o nível da sociedade como um todo. O que o autor sugere é que essas condições moldam e são moldadas pelo discurso. A seguir, o diagrama proposto por Fairclough:

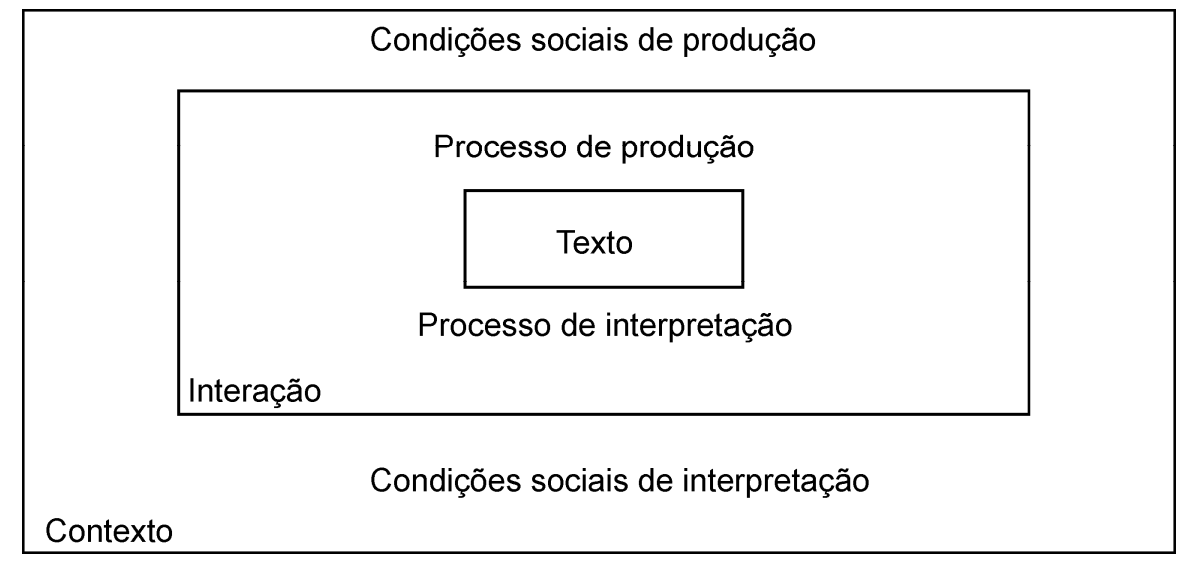

FIGURA 2. Discurso como texto, interação e contexto (FAIRCLOUGH, 1989, p. 25)

Então, a partir do diagrama que enfatiza as dimensões do discurso, Fairclough realiza uma correspondência com três dimensões de análise crítica do discurso: 
- A descrição (texto) é o estágio que se preocupa com propriedades formais do texto.

- A interpretação (discurso) se ocupa com a relação entre texto e interação, ou seja, analisa o texto como um produto de um processo de interação e como um recurso de interpretação.

- A explicação (social) está preocupada com a relação entre interação e contexto social. Em outros termos, centra-se na determinação social do processo de produção e interpretação, e seus efeitos sociais.

Essas etapas serão revistas adiante, pois farão parte do processo de análise do gênero ombudsman.

É importante comentar que a análise realizada é diferente em cada estágio. Na fase da descrição, privilegia-se o léxico, as escolhas gramaticais, a estrutura do texto e os elementos de coesão. Para o autor, mesmo em uma análise formal, deve-se considerar o elemento interpretativo, já que se está lidando com material simbólico. A fase de interpretação toma o texto considerando aspectos relacionados à produção, recepção e interpretação por parte dos atores sociais. Considera ainda as vozes que atravessam o texto, elemento fundamental de análise. Por fim, o terceiro nível procura analisar as questões hegemônicas e ideológicas presentes no universo textual.

\subsubsection{Discurso e poder}

Ao discutir as relações entre poder e discurso, Fairclough (1989) realiza considerações em sessões separadas. Primeiramente fala do poder no discurso, como um lugar de relações face a face. Depois, discute o poder por trás do discurso e demonstra como o discurso das instituições sociais é constituído por relações de poder. Diz que o poder, na realidade, não pertence à instituição em si, mas aos seus titulares. Para explicitar o poder na relação face a face, o autor apresenta uma série de exemplos que demonstra como o poder no discurso é usado para persuadir. Dentre esses exemplos, cita casos de entrevistadores influenciando as respostas de seus entrevistados (relações de controle e subordinação). Relata ainda o exercício do poder da mídia em relação aos consumidores e a operacionalização da imprensa (britânica) para manter e reproduzir o discurso da classe dominante.

No poder por trás do discurso, Fairclough apresenta como exemplo o discurso da instituição médica. Discorre sobre como a forma do posicionamento e do comportamento do médico é estabelecida por determinadas convenções profissionais, que devem ser mantidas. A própria postura do profissional diante do paciente, o que pode ou não ser dito, a vestimenta, o local de atendimento, são alguns dos aparatos que servem aos encalços da instituição, tornando o discurso do médico legítimo. Meurer (2005) exemplifica esse poder com a instituição escolar, que se manifesta até mesmo diante da adoção de determinados livros didáticos por parte da escola em detrimento de outros. 


\subsubsection{Discurso e mudança social}

Fairclough (1989), em sua explanação a respeito da função do discurso na mudança social, discorre sobre três tipos de discurso: o discurso publicitário, o discurso de tecnologias e burocracia e, por fim, o discurso terapêutico. Ilustraremos a intenção do autor por meio da apresentação de um dos tipos de discurso, o publicitário, já que este é suficiente para compreendermos parte importante do que Fairclough pretende ao enunciar mudança social e discurso.

Para o autor, o discurso publicitário representa uma forma de colonização na vida das pessoas dentro da ordem do discurso. Relata como tal discurso é estratégico, orientado pela busca de um consenso entre os participantes da situação enunciativa. Assim, o consumismo, produto do capitalismo maduro, tem por objetivo único transformar pessoas em consumidores em potencial, na medida em que cria necessidades e valores (faz as pessoas acreditarem que necessitam do produto - opera uma mudança social). Fairclough (1989) cita excertos de um código britânico que intenta regular a atividade propagandística na Inglaterra. Os trechos denotam preocupações que levam ao controle dos níveis mais superficiais da propaganda no que diz respeito à sua natureza como comunicação estratégica e persuasão, mas ignora o que para o autor é mais relevante, que é o trabalho ideológico da publicidade.

Fairclough salienta, ainda com relação ao discurso publicitário, que os anúncios trabalham ideologicamente no sentido de: (a) construir relações (relação entre o produtor/anunciante do produto que está sendo anunciado e o público-espectador); (b) construir imagens, onde se objetiva criar uma imagem para o produto que está sendo anunciado; e (c) construir o consumidor, em que se criam posições subjetivas de consumidores como membros das comunidades de consumo, sendo este o grande trabalho de publicidade ideológica. $\mathrm{O}$ autor exemplifica tais considerações com um anúncio de uma máquina de lavar roupas. Diz como o texto publicitário opera na personalização do consumidor: "Você não terá mais dias ruins"; "É um relaxamento para sua mente". Nestes excertos do anúncio, o você e as frases imperativas tem a função de criar um remetente individual. Também apresenta imagens que remetem a um estilo de vida moderno e a lavadora, obviamente, deverá fazer parte desse estilo. Nesse sentido, todo o aparato comercial faz parte de uma construção ideológica em grande escala. A moldura empacota juntamente questões sociais, numa poderosa prescrição de como se deve viver, ou, pelo menos, como se deve reconhecer a melhor forma de viver, no mundo moderno, juntamente com o mito de que essa vida é acessível a todos.

\subsubsection{Discurso e ideologia}

Fairclough (2001, p. 117a) assim define as ideologias: "As ideologias são significações/construções da realidade (o mundo físico, as relações sociais, as identidades sociais) que são construídas em várias dimensões das formas/sentidos das práticas discursivas e que contribuem para a produção, a reprodução ou a transformação das relações de dominação". Uma determinada representação pode ser considerada ideológica na medida em que contribui, ou não, para a manutenção ou estabelecimento de relações de dominação. Resende e Ramalho (2006) afirmam que a 
noção de ideologia da ACD carrega um efeito eminentemente negativo, na medida em que postula que a ideologia é por natureza hegemônica, pois se presta a manter situações de dominação, reproduzindo o caminho social que favorece certos grupos considerados dominantes. Desse modo, o conceito de ideologia se afasta de concepções neutras que desconsideram que a ideologia implica a sustentação de interesses de um grupo particular e que, dessa forma, se presta à constituição das relações assimétricas de poder. Os modos de operacionalização da ideologia na ACD provêm dos postulados de Thompson (1995). São eles: legitimação, dissimulação, unificação, fragmentação e reificação.

A legitimação sustenta relações de dominação na medida em que impõe um caráter de justiça nas relações sociais, tornando o discurso da classe privilegiada legítimo. Afirmações de legitimação se baseiam em três mecanismos de construção simbólica: racionalização, universalização e narrativização. O primeiro elemento da legitimação se apóia na legalidade de regras que já estão na ordem do dado; a universalização opera por meio de representações que são legitimadas tomando-se como escopo o pressuposto de que servem aos interesses gerais; e, por fim, a narrativização se constrói através de histórias que encontram no passado uma maneira de legitimar o presente.

A dissimulação, por sua vez, opera na ideologia sustentando relações de dominação por meio de sua negação ou ofuscação. Realiza-se em três mecanismos: deslocamento, eufemização e tropo. A primeira dessas construções simbólicas, o deslocamento, ocorre em um processo de recontextualização de termos, que se referem a um campo, mas que são dirigidos a outro campo, no qual são deslocadas conotações positivas ou negativas. Na eufemização, busca-se uma valoração positiva em relação às ações, relações ou instituições, minimizando-se possíveis instabilidades. Já o tropo está relacionado ao uso metafórico da linguagem, que pode servir como forma de amenização para relações de conflito.

Quanto à unificação, significa o estabelecimento de relações de dominação sustentadas pela construção simbólica da unidade. São duas as estratégias de construção simbólica desse elemento: a padronização e a simbolização. A primeira se refere à assimilação de um padrão referencial partilhado. A simbolização remete à construção de símbolos de identificação coletiva.

Na fragmentação, as relações de domínio são mantidas através da separação de pessoas e agrupamentos que, se unidos, poderiam representar um obstáculo para a manutenção do poder. Um de seus elementos, ou seja, estratégias de construção simbólica, é a diferenciação, que tem por objetivo desestabilizar a luta hegemônica por meio do impedimento da formação de grupos coesos.

Por fim, a reificação representa um modo de operação da ideologia em que se intenta apresentar uma situação transitória como fixa através da omissão de seu caráter sóciohistórico. As estratégias são: naturalização (uma criação social é tratada como natural), eternalização (fenômenos históricos são considerados permanentes), nominalização e passivação (nessas duas estratégias há o apagamento de ações e de atores, representando processos como entidades). 
Apresentamos o quadro proposto por Resende e Ramalho (2006) que resume o arcabouço de construções simbólicas ideológicas de Thompson.

QUADRO 1. Modos gerais de operação da ideologia

\begin{tabular}{|c|c|}
\hline $\begin{array}{l}\text { MODOS GERAIS DE OPERAÇÃO DA } \\
\text { IDEOLOGIA }\end{array}$ & $\begin{array}{l}\text { ESTRATÉGIAS TÍPICAS DE CONSTRUÇÃO } \\
\text { SIMBÓLICA }\end{array}$ \\
\hline \multirow{3}{*}{$\begin{array}{l}\text { LEGITIMAÇÃO } \\
\text { Relações de dominação são representadas } \\
\text { como legítimas }\end{array}$} & $\begin{array}{l}\text { RACIONALIZAÇÃO (uma cadeia de raciocínio } \\
\text { procura justificar um conjunto de relações) }\end{array}$ \\
\hline & $\begin{array}{l}\text { UNIVERSALIZAÇÃO (interesses específicos são } \\
\text { apresentados como interesses gerais) }\end{array}$ \\
\hline & $\begin{array}{l}\text { NARRATIVIZAÇÃO (exigências de legitimação } \\
\text { inseridas em histórias do passado que legitimam o } \\
\text { presente) }\end{array}$ \\
\hline \multirow{3}{*}{$\begin{array}{l}\text { DISSIMULAÇÃO } \\
\text { Relações de dominação são ocultadas, } \\
\text { negadas ou obscurecidas }\end{array}$} & $\begin{array}{l}\text { DESLOCAMENTO (deslocamento contextual de } \\
\text { termos e expressões) }\end{array}$ \\
\hline & $\begin{array}{l}\text { EUFEMIZAÇÃO (valoração positiva de } \\
\text { instituições , ações ou reações) }\end{array}$ \\
\hline & TROPO (sinédoque, metonímia, metáfora) \\
\hline \multirow{2}{*}{$\begin{array}{l}\text { UNIFICAÇÃO } \\
\text { Construção simbólica de identidade coletiva }\end{array}$} & $\begin{array}{l}\text { PADRONIZAÇÃO (um referencial padrão } \\
\text { proposto como fundamento compartilhado) }\end{array}$ \\
\hline & $\begin{array}{l}\text { SIMBOLIZAÇÃO DA UNIDADE (construção de } \\
\text { símbolos de unidade e identificação coletiva) }\end{array}$ \\
\hline \multirow{2}{*}{$\begin{array}{l}\text { FRAGMENTAÇÃO } \\
\text { Segmentação de indivíduos e grupos que } \\
\text { possam representar ameaça ao grupo } \\
\text { dominante }\end{array}$} & $\begin{array}{l}\text { DIFERENCIAÇÃO (ênfase em características que } \\
\text { desunem e impedem a constituição de desafio } \\
\text { efetivo) }\end{array}$ \\
\hline & $\begin{array}{l}\text { EXPURGO DO OUTRO (construção simbólica de } \\
\text { um inimigo) }\end{array}$ \\
\hline \multirow{3}{*}{$\begin{array}{l}\text { REIFICAÇÃO } \\
\text { Retratação de uma situação transitória como } \\
\text { permanente e natural }\end{array}$} & $\begin{array}{l}\text { NATURALIZAÇÃO (criação social e histórica } \\
\text { tratada como acontecimento natural) }\end{array}$ \\
\hline & $\begin{array}{l}\text { ETERNALIZAÇÃO (fenômenos sócio-históricos } \\
\text { apresentados como permanentes) }\end{array}$ \\
\hline & $\begin{array}{l}\text { NOMINALIZAÇÃO/PASSIVAÇÃO } \\
\text { (concentração da atenção em certos temas em } \\
\text { detrimento de outros, com apagamento de atores e } \\
\text { ações) }\end{array}$ \\
\hline
\end{tabular}

Fonte: Resende e Ramalho (2006, p. 52)

A relevância dessa abordagem para a ACD é a construção de mecanismos para análise das constituições simbólicas no discurso. Em outros termos, a proposta de Thompson (1995) para a análise da ideologia unida à vertente da ACD fornece subsídios para que se analisem linguisticamente processos discursivos revestidos de ideologia.

Fairclough (2003a, 2003b) diz que ideologias são, a priori, representações; no entanto, podem se legitimar em formas de ação social. Tal entendimento se baseia na noção de gêneros, discursos e estilos conforme a proposta do autor (amparada no funcionalismo de Halliday) de considerar o discurso em meio a três tipos de significado: representacional (discursos); acional (ligado a gêneros) e identificacional (relacionado a estilos). Na próxima seção, discutiremos em maiores detalhes a relação dialética estabelecida entre eles. 


\subsection{Linguística Sistêmico Funcional (LSF) e ACD}

Análises de discurso críticas são direcionadas, como já comentamos, linguística e socialmente. Nesta seção focalizaremos a face linguística. Importante ressaltar que tal divisão é realizada para fins didáticos, uma vez que no trabalho analítico torna-se impossível essa separação. Desse modo, abordamos a recontextualização da LSF em Fairclough (2003a), enfatizando de que forma as macrofunções de Halliday foram operacionalizadas para originar os três tipos de significados de Fairclough.

O entendimento das implicações das relações (funções) sociais é relevante para o estudo que interconecta linguagem e sociedade. Disso vem a necessidade de se analisar os sistemas internos das línguas naturais sob o escopo das funções sociais (RESENDE e RAMALHO, 2006).

As vertentes funcionais têm enfatizado o caráter multifuncional da linguagem e, dessa forma, Halliday (1991) registra três macrofunções, que em conjunto atuam nos textos. São elas: a ideacional, a interpessoal e a textual. A primeira é a função da linguagem que remete à representação da experiência, uma forma de refletir a "realidade" na língua; os enunciados remetem a processos (eventos, ações) da atividade humana por meio de uma relação simbólica. Essa função considera a expressão linguística do conteúdo ideacional existente nos usos da linguagem. A função interpessoal interessase pelo significado, considerando a função na interação social, da língua vista como ação. Trata dos usos da língua na expressão dos processos relacionais. A terceira função - a textual - analisa aspectos gramaticais, estruturais e semânticos nos textos (guiados por aspectos funcionais).

As macrofunções são inter-relacionadas levando a entender que todo e qualquer enunciado é multifuncional, servindo simultaneamente a várias funções. Sendo assim, as estruturas linguísticas atuam de forma integrada em todos os componentes funcionais do enunciado.

Em sua obra Analysing Discourse, Fairclough (2003a) amplia o diálogo entre a ACD e a LSF, propondo um imbrincamento entre as macrofunções e as noções de gênero, discurso e estilo, sugerindo, ao invés das funções, três significados: o acional, o representacional e o identificacional. Conforme Resende e Ramalho (2006, p.60):

A operacionalização dos três significados mantém a noção de multifuncionalidade presente na LSF, uma vez que Fairclough enfatiza que os três atuam simultaneamente em todo enunciado. Ele explica que o discurso figura de três principais maneiras como parte de práticas sociais, na relação entre textos e eventos: como modos de agir, como modos de representar e como modos de ser. A cada um desses modos de interação entre discurso e prática social corresponde um tipo de significado. O significado acional focaliza o texto como modo de (inter)ação em eventos sociais, aproxima-se da função relacional, pois a ação legitima/questiona relações sociais; o significado representacional enfatiza a representação de aspectos do mundo - físico, mental, social - em textos, aproximando-se da função ideacional, e o significado identificacional, por sua vez, 
refere-se à construção e à negociação de identidades no discurso, relacionando-se à função identitária ${ }^{5}$.

Fairclough (2003a) realiza uma relação entre ação e gêneros, representação e discursos, identificação e estilos, sendo que gêneros, discursos e estilos são encarados como formas relativamente estáveis de agir, de representar e de identificar, respectivamente. A análise do discurso gira em torno de se conhecer como os três significados, materializados nos traços linguísticos presentes nos textos, interconectam-se com práticas sociais, observando-se quais gêneros, discursos e estilos perfazem o texto em questão.

\subsubsection{Significado acional}

Gêneros representam "o aspecto especificamente discursivo de maneiras de ação e interação no decorrer de eventos sociais" (FAIRCLOUGH, 2003a, p.65). Quando um texto é analisado em termos de gênero, tem-se como enfoque a descoberta da maneira como o texto figura na inter(ação) social e de que forma contribui nessa interação através de eventos sociais concretos.

O significado acional pode ser analisado (nos textos) em meio a uma série de categorias expressas na obra de Fairclough (2003a). Aqui nos restringiremos a apenas uma delas: o dialogismo. Bakhtin (2003) diz que textos são dialógicos por natureza, porque são parte de uma cadeia de textos (anteriores e posteriores a eles). Uma categoria de análise ancorada nesse conceito se baseia no mapeamento de quais vozes (discurso direto, indireto, velado) são incluídas e quais são excluídas no texto. Também se observa a articulação entre essas vozes no universo textual. Interessante considerar que a relação entre essas vozes pode ser de cooperação ou discordância. A análise de tais aspectos pode estar fortemente relacionada às questões de poder no uso da linguagem. A dialogicidade é bastante variável de texto para texto. Em alguns, há pouca visibilidade do discurso alheio (representações referidas sem serem relatadas). Em outros casos, é possível que haja uma abstração do que realmente foi dito. Por meio da análise das escolhas linguísticas presentes no texto é possível descobrir o grau de engajamento do locutor com o que enuncia, quer dizer, se ela aceita ou refuta o discurso de outrem.

Fairclough (1995) dispõe algumas formas pelas quais se transforma um discurso direto em indireto, delimitando uma fronteira entre as vozes: (1) uso de verbos dicendi acrescido de oração subordinada (ele falou que..); (2) passagem de pronomes de primeira e segunda pessoas para pronomes de terceira pessoa; (3) mudança nos dêiticos; e (4) verbos são colocados no tempo passado.

\footnotetext{
5 Fairclough, em 1992, sugeriu a cisão da função interpessoal em duas funções distintas, a função identitária e a função relacional. A identitária está relacionada à forma como as identidades sociais são estabelecidas no discurso. A relacional explica como as relações entre os atores do discurso são negociadas.
} 


\subsubsection{Significado representacional}

O significado representacional é relacionado à noção de discurso como forma de representação de aspectos do mundo. Os discursos, como os gêneros, também variam em estabilidade e escala. Um único texto pode conter vários tipos de discurso e a articulação entre eles pode se dar de várias formas, indo da cooperação à competição (RESENDE E RAMALHO, 2006). As autoras afirmam que um mesmo aspecto do discurso pode ser representado por meio de diferentes discursos, sendo esta heterogeneidade denominada interdiscursividade. A análise desses aspectos está relacionada à identificação e articulação dos discursos que compõem o texto. Para que se identifique um discurso é preciso que se descubram as temáticas centrais (partes do mundo representadas nos textos) e também que se investigue a partir de que perspectiva ocorre essa representação. Tal análise pode se dar pelo mapeamento dos traços linguísticos que realizam o discurso. $\mathrm{O}$ mais evidente nesses traços, conforme Fairclough (2003a), é o vocabulário, já que distintos discursos lexicalizam o mundo de formas variadas.

Outra categoria analítica que pode ser usada no acesso ao significado representacional nos textos é a representação de atores sociais. As estratégias de representações dos participantes do discurso podem sugerir posicionamentos ideológicos em relação a eles e às suas atividades. "Determinados atores, por exemplo, podem ter sua agência ofuscada ou enfatizada em representações, podem ser representados por suas atividades ou enunciados ou, ainda, podem ser referidos de modos que presumem julgamentos acerca do que são ou do que fazem. Por isso, a análise de tais representações pode ser útil no desvelamento de ideologias em textos e interações" (RESENDE e RAMALHO, 2006, p.72).

Mais uma categoria de análise do significado representacional discutida aqui é a de significado de palavra (FAIRCLOUGH, 2001a). Para o autor, os "significados das palavras" e a "lexicalização de significados" não são construtos individuais e, sim, sociais; são considerados "facetas de processos culturais e sociais mais amplos". Podemos ilustrar a influência do vocabulário expresso no discurso da mídia, por exemplo, dizer "o presidente do Brasil, Luis Inácio Lula da Silva" ou "o exmetalúrgico, presidente do Brasil", referindo-se ao mesmo indivíduo físico, já denota um posicionamento expresso no dito, que revela possíveis lutas hegemônicas e de filiação de certo discurso, tentando universalizar uma representação particular de mundo.

\subsubsection{Significado ideacional}

O significado ideacional está relacionado à noção de estilo. O estilo está ligado ao aspecto discursivo da identificação de atores sociais nos textos (identidades). Identidade e diferença são conceitos estritamente vinculados. É através da representação que identidade e diferença se atrelam a estruturas de poder; questionar identidades e diferenças é, conforme Fairclough (2003a), questionar a legitimidade dos sistemas que lhes servem de apoio na atribuição de sentido. Tal afirmação ilustra a dialética entre os três significados (acional, representacional e ideacional). 
Entre as categorias de análise relacionadas ao significado ideacional, destacamos a modalidade para ser discutida neste espaço.

De acordo com Halliday (1985, p.85), a modulação é "o julgamento do falante sobre as probabilidades ou obrigatoriedades envolvidas no que diz". Conforme o autor, a modulação associa-se à polaridade (escolha entre os "polos" positivo e negativo; é ou não é), que é "um traço semântico essencial". A modalidade, por sua vez, indica possibilidades intermediárias; fica entre o sim e o não (indeterminação situada entre os polos). A modalidade se relaciona aos níveis intermediários entre os polos em proposições, quer dizer, os graus de probabilidade (provável, possível, certo) e frequência (usual, esporádico, frequente). Já o termo modulação se atrela às escalas de obrigatoriedade (obrigatório, permitido, proibido) e inclinação (desejoso, ansioso, determinado). Esta proposta foi sintetizada por Resende e Ramalho (2006) no quadro a seguir:

QUADRO 2. Modalidade e modulação

\begin{tabular}{|c|c|c|c|c|c|c|}
\hline $\begin{array}{c}\text { TROCA } \\
\text { DE }\end{array}$ & \multicolumn{2}{|c|}{$\begin{array}{c}\text { FUNÇÃO } \\
\text { DISCURSIVA }\end{array}$} & \multicolumn{2}{|c|}{ TIPO DE INTERMEDIAÇÃO } & $\begin{array}{c}\text { REALIZAÇÃO } \\
\text { TÍPICA }\end{array}$ & EXEMPLO \\
\hline \multirow{6}{*}{ Informação } & \multirow{6}{*}{ proposição } & \multirow{6}{*}{$\begin{array}{l}\text { afirmação } \\
\text { pergunta }\end{array}$} & \multirow{6}{*}{ Modalidade } & \multirow{3}{*}{$\begin{array}{l}\text { probabilidade } \\
\text { (possível/ } \\
\text { provável/ } \\
\text { certo) }\end{array}$} & verbo modal & $\begin{array}{l}\text { Eles devem } \\
\text { ter sabido. }\end{array}$ \\
\hline & & & & & advérbio modal & $\begin{array}{l}\text { Eles } \\
\text { certamente } \\
\text { souberam. }\end{array}$ \\
\hline & & & & & Ambos & $\begin{array}{l}\text { Eles } \\
\text { certamente } \\
\text { devem ter } \\
\text { sabido. } \\
\end{array}$ \\
\hline & & & & \multirow{3}{*}{$\begin{array}{l}\text { frequência } \\
\text { (às vezes/ } \\
\text { frequentemente } \\
\text { / sempre) }\end{array}$} & verbo modal & $\begin{array}{l}\text { Isso pode } \\
\text { acontecer. }\end{array}$ \\
\hline & & & & & advérbio modal & $\begin{array}{l}\text { Isso sempre } \\
\text { acontece. }\end{array}$ \\
\hline & & & & & Ambos & $\begin{array}{l}\text { Isso sempre } \\
\text { pode } \\
\text { acontecer. }\end{array}$ \\
\hline \multirow{4}{*}{$\begin{array}{l}\text { bens e } \\
\text { serviços }\end{array}$} & \multirow{4}{*}{ proposta } & \multirow{4}{*}{$\begin{array}{l}\text { ordem } \\
\text { oferta }\end{array}$} & \multirow{4}{*}{ modulação } & \multirow{2}{*}{$\begin{array}{l}\text { obrigação } \\
\text { (permitido/ } \\
\text { esperado/ } \\
\text { exigido) }\end{array}$} & verbo modal & $\begin{array}{l}\text { Você precisa } \\
\text { ser paciente. }\end{array}$ \\
\hline & & & & & $\begin{array}{l}\text { predicador verbal } \\
\text { (-se) }\end{array}$ & $\begin{array}{l}\text { Exige-se que } \\
\text { você tenha } \\
\text { paciência. }\end{array}$ \\
\hline & & & & \multirow{2}{*}{$\begin{array}{l}\text { inclinação } \\
\text { (desejo/ } \\
\text { ansiedade/ } \\
\text { inclinação) }\end{array}$} & Verbo & $\begin{array}{l}\text { Eu quero } \\
\text { ajudar. }\end{array}$ \\
\hline & & & & & $\begin{array}{l}\text { predicador } \\
\text { adjetivo }\end{array}$ & $\begin{array}{l}\text { Estou } \\
\text { determinado } \\
\text { a ajudar. }\end{array}$ \\
\hline
\end{tabular}

Fonte: Resende e Ramalho (2006, p.82)

Fairclough (2003a) modifica a teoria de Halliday acerca da modalidade. Em primeiro lugar, unifica os dois termos modalidade e modulação em um único termo, modalidade. Para o autor, a questão da modalidade está relacionada ao comprometimento das pessoas com o dito; com suas afirmações, perguntas, demandas ou ofertas. Assim, afirmações e perguntas remetem à troca de conhecimento ${ }^{6}$. Demandas ou ofertas, por sua vez, dizem respeito à troca de atividade ${ }^{7}$. Em troca de conhecimento a modalidade é do tipo epistêmica (relacionada ao comprometimento

\footnotetext{
${ }^{6}$ Remete à troca de informação de Halliday.

${ }^{7}$ Equivale à troca de bens e serviços de Halliday.
} 
com a verdade). Nas trocas de atividade a modalidade é deôntica (comprometimento com a obrigatoriedade).

Outra diferença entre os postulados de Halliday e Fairclough é que enquanto o primeiro se preocupa, com relação à modalidade, exclusivamente com o intermediário entre os polos, Fairclough fornece uma definição mais ampla que abarca os extremos (asserção e negação absolutas). Sugere, desse modo, uma modalidade categórica. Também fornece uma reflexão entre distinções temporais (pode/poderia; deve/deveria).

Outra distinção proposta por Fairclough (2001a) ocorre entre a modalidade objetiva e modalidade subjetiva. Na objetiva, a base subjetiva do julgamento não é precisa (o locutor oferece seu ponto de vista como universal ou age em nome de outro sujeito ou grupo de pessoas?). $\mathrm{Na}$ modalidade subjetiva, a base subjetiva fica expressa determinando a afinidade do falante.

Resende e Ramalho (2006, p.84) afirmam que "a realização clássica da modalidade são os verbos e advérbios modais com os adjetivos correspondentes. Não obstante, há uma gama de outros fenômenos linguísticos e paralinguísticos que deve ser considerada". Para ilustrar essa questão citam, a partir de Maingueneau, os advérbios e locuções adverbiais como talvez, felizmente; interjeições; os adjetivos como desejável, indiscutivel; os verbos; a entonação; as glosas metaenunciativas (de qualquer forma...); as ironias; o discurso citado; os sinais como aspas etc.

O estudo da modalidade é relevante na construção discursiva de identidades, pois o comprometimento com o dito revela uma parte significativa da pessoa que diz, então, escolhas de modalidade em textos podem ser concebidas como parte do processo de formação de autoidentidades (FAIRCLOUGH, 2003a).

Entretanto, como o processo de identificação é atingido pelo de relações sociais, as escolhas de modalidade são relevantes não apenas na construção de identidades, mas também na ligação entre modalidade e hegemonia, perfazendo a dialética entre os três significados (FAIRCLOUGH, 2001b). Para o autor isso quer dizer que se um texto tem prevalência de modalidades categóricas (alto compromisso com o dito) e as modalidades são em sua maioria do tipo objetivas (quando o autor não expõe a base de seu comprometimento), resulta em um efeito de universalização da visão defendida no discurso, que é concebida como verdadeira, uma vez que não há traços dessa perspectiva como pertencendo a um indivíduo em particular.

\section{APARATO METODOLÓGICO}

Nesta seção, apresentamos a metodologia do estudo. Inicialmente, estabelecemos os objetivos gerais e específicos. Em seguida, alistamos as questões de pesquisa formuladas para guiar o estudo. Por fim, descrevemos em linhas gerais o corpus do estudo. 


\subsection{Objetivos}

O objetivo geral deste estudo é investigar o gênero ombudsman, no que diz respeito à construção de identidades e aos modos de operação da ideologia para manutenção de uma posição hegemônica do jornal em relação aos leitores.

\section{São objetivos específicos:}

a) mediante análise dos participantes dos processos verbais expressos por verbos dicendi, verificar a mobilização de dizentes pelo ombudsman;

b) mediante análise do léxico e das relações sintático-semânticas, verificar as estratégias de construção simbólica manifestas nas colunas;

c) com base nos dados anteriormente gerados, verificar quais relações sociais o ombudsman constrói com seus leitores, que identidade ele constrói para si mesmo e quais os modos de operação da ideologia para manter a posição hegemônica do jornal em relação aos leitores.

\subsection{Questões de pesquisa}

Três questões de pesquisa guiam a análise:

a) Em que medida o ombudsman se vale de outros dizentes para exercer a crítica ao jornal?

b) De quais estratégias de construção simbólica o ombudsman lança mão?

c) Que identidade social o ombudsman constrói, isto é, em que medida, ele é um crítico do fazer jornalístico e um representante do leitor e em que medida ele é um representante do jornal como força hegemônica?

\subsection{Corpus}

O corpus deste estudo é constituído das colunas de ombudsman dos jornais Folha de S. Paulo, do estado de São Paulo, e O Povo, do estado do Ceará, publicadas nos meses de agosto e setembro de 2009, num total de 18 colunas. Assinam essas colunas, respectivamente, os jornalistas Carlos Eduardo Lins da Silva e Rita Célia Faheina. Por maior facilidade, acessaram-se as publicações eletrônicas desses jornais, nos sítios eletrônicos http://wwwl.folha.uol.com.br/folha/ombudsman/ http://opovo.uol.com.br/opovo/colunas/ombudsman/ ${ }^{8}$.

A coluna de Silva (Folha de S. Paulo) compreende duas ou três páginas eletrônicas, com os seguintes itens:

- Na primeira página: local e data, seguido do título "ombudsman"; links para o próximo texto e para o índice; identificação do jornalista; endereço eletrônico do ombudsman; título do primeiro texto (geralmente, cada coluna

\footnotetext{
${ }^{8}$ No Anexo, apresentamos os links para todas as colunas analisadas.
} 
compreende dois textos de maior extensão); olho do primeiro texto; corpo do primeiro texto; indicação de leitura (sob o título "Para ler"); indicação de filme, documentário (sob o título "Para ver"); links para o próximo texto e para o índice; informações sobre Carlos Eduardo Lins da Silva e sobre o cargo de ombudsman; endereços e telefone para contactar o jornal;

- Na segunda página: local e data, seguido do título "ombudsman"; links para o texto anterior, para o próximo texto e para o índice; título do segundo texto; corpo do segundo texto; links para o texto anterior, para próximo texto e para o índice; informações sobre Carlos Eduardo Lins da Silva e sobre o cargo de ombudsman; endereços e telefone para contactar o jornal;

- Na terceira página: local e data, seguido do título "ombudsman"; links para o texto anterior e para o índice; elogios ao jornal (Sob o título "Onde a Folha foi bem...”); críticas negativas ao jornal (Sob o título “... e onde foi mal"); assuntos mais comentados da semana (sob esse mesmo título); gráfico da proporção de ocupação da seção Painel do Leitor por cartas de leitores ou de pessoas que foram notícia (sob o título "De quem é o painel?"); assuntos que o jornal deixou de retomar (sob o título "Pró memória"); links para o texto anterior e para o índice; endereços e telefone para contactar o jornal.

A coluna de Faheina, no jornal $O$ Povo, compreende uma só página, com estes itens: título da coluna ("Ombudsman"); links para outras seções da versão eletrônica do jornal; link para uma descrição do cargo de ombudsman; link para uma história do cargo de ombudsman; link para documentos relativos a ética e cidadania; link para a página da ombudsman emérita; repetição do título "ombudsman", em corpo menor; título do primeiro texto; nome da ombudsman; endereço eletrônico da ombudsman; data e hora (possivelmente da postagem no sítio); corpo do texto; do lado direito, links para textos publicados anteriormente na coluna da ombudsman (sob o título "Textos anteriores"); do lado direito, logo abaixo dos "Textos anteriores", links para notícias do jornal (sob o título "Outras notícias"); logo abaixo do primeiro texto, título e corpo do segundo texto (nem todas as colunas analisadas apresentam o segundo texto); link para o leitor avaliar o texto, com uma pontuação em estrelas; link para o leitor compartilhar o texto; espaço para o leitor comentar o texto, seguido de breves regras quanto ao uso desse espaço; endereço, fax, telefone e e-mail para contato com a ombudsman; horário de atendimento ao leitor; breve perfil biográfico e profissional de Rita Célia Faheina, acompanhado de foto; links para outras seções do jornal.

A título de exemplo, reproduzimos abaixo o topo e o pé de uma primeira página de Silva, seguindo-se o topo e o pé de uma página de Faheina. 


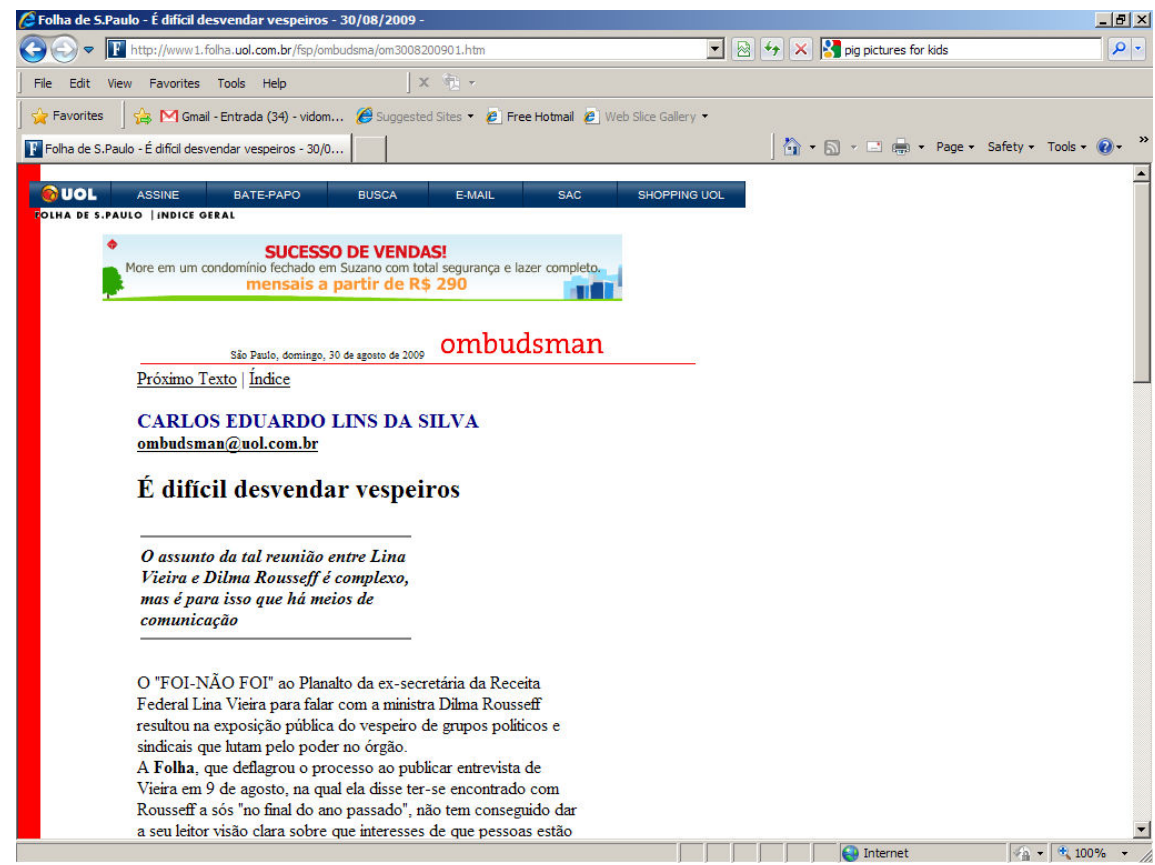

FIGURA 3. Página eletrônica da coluna de Silva (início)

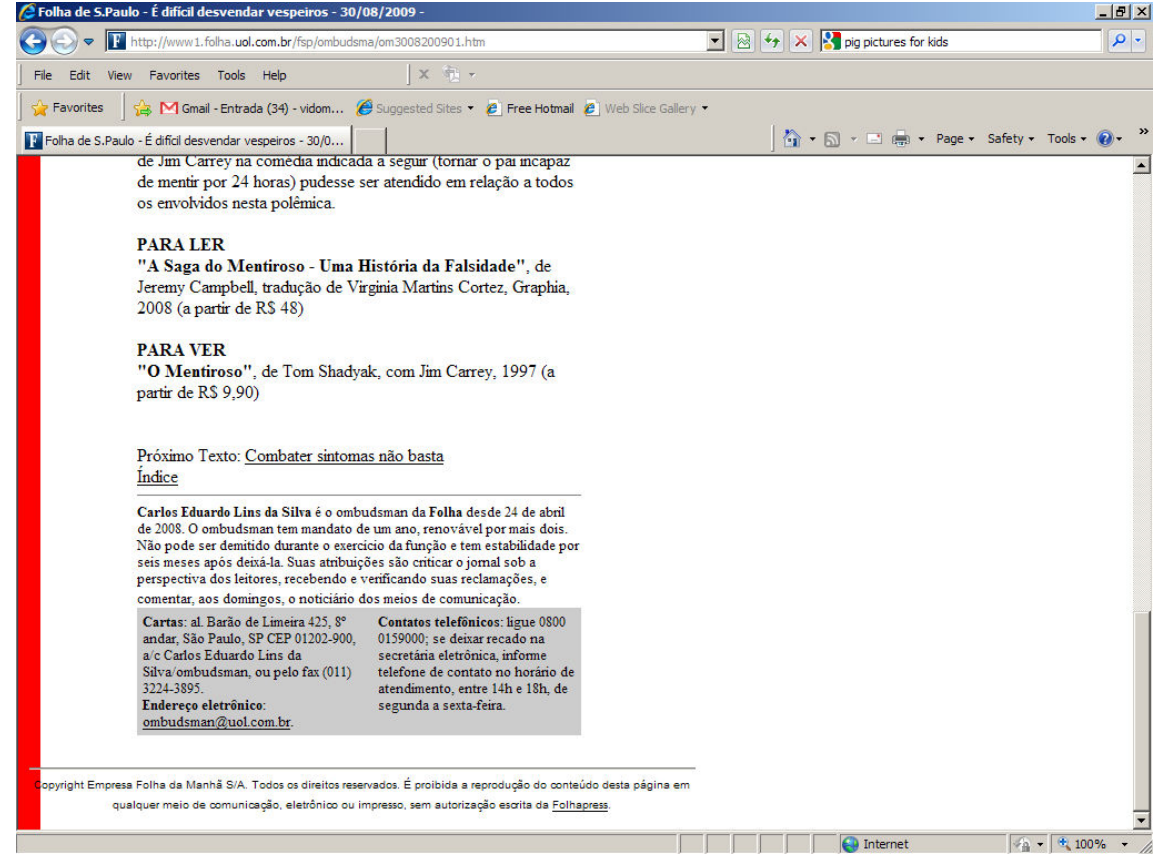

FIGURA 4. Página eletrônica da coluna de Silva (final) 


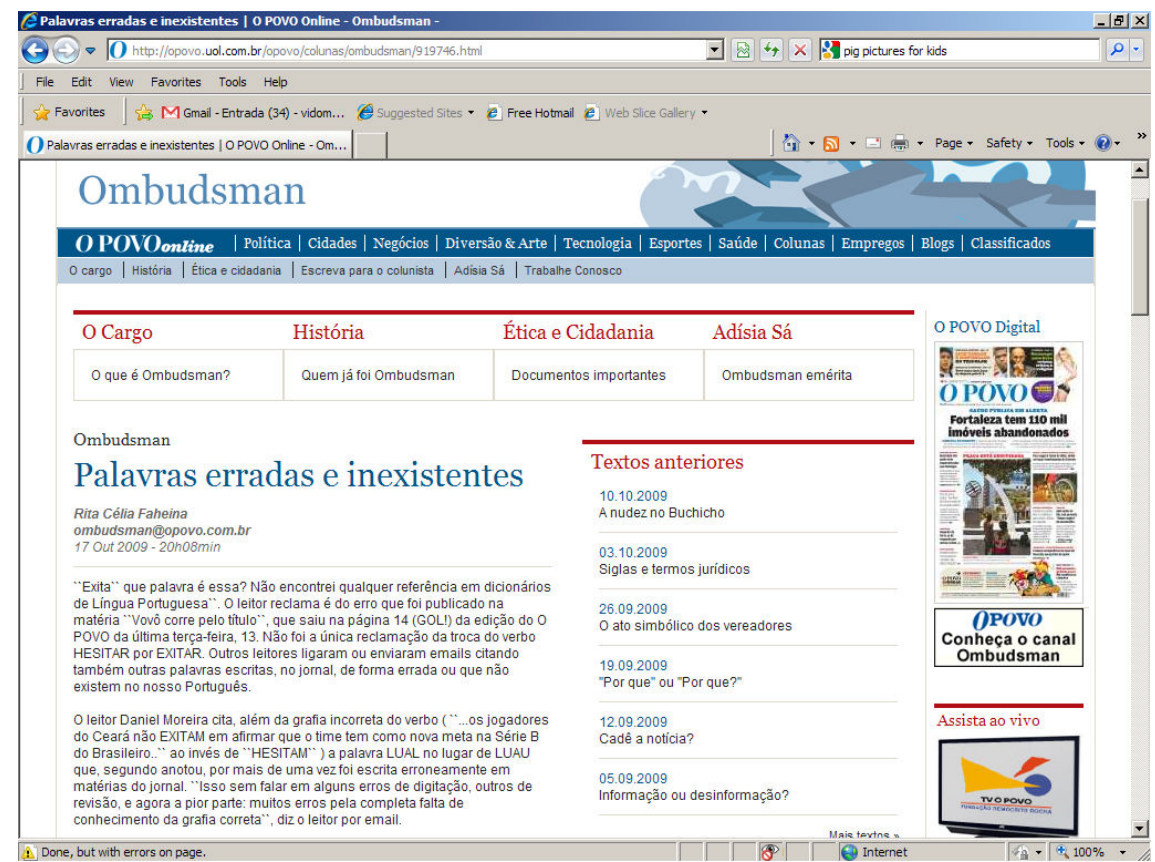

FIGURA 5. Página eletrônica da coluna de Faheina (início)

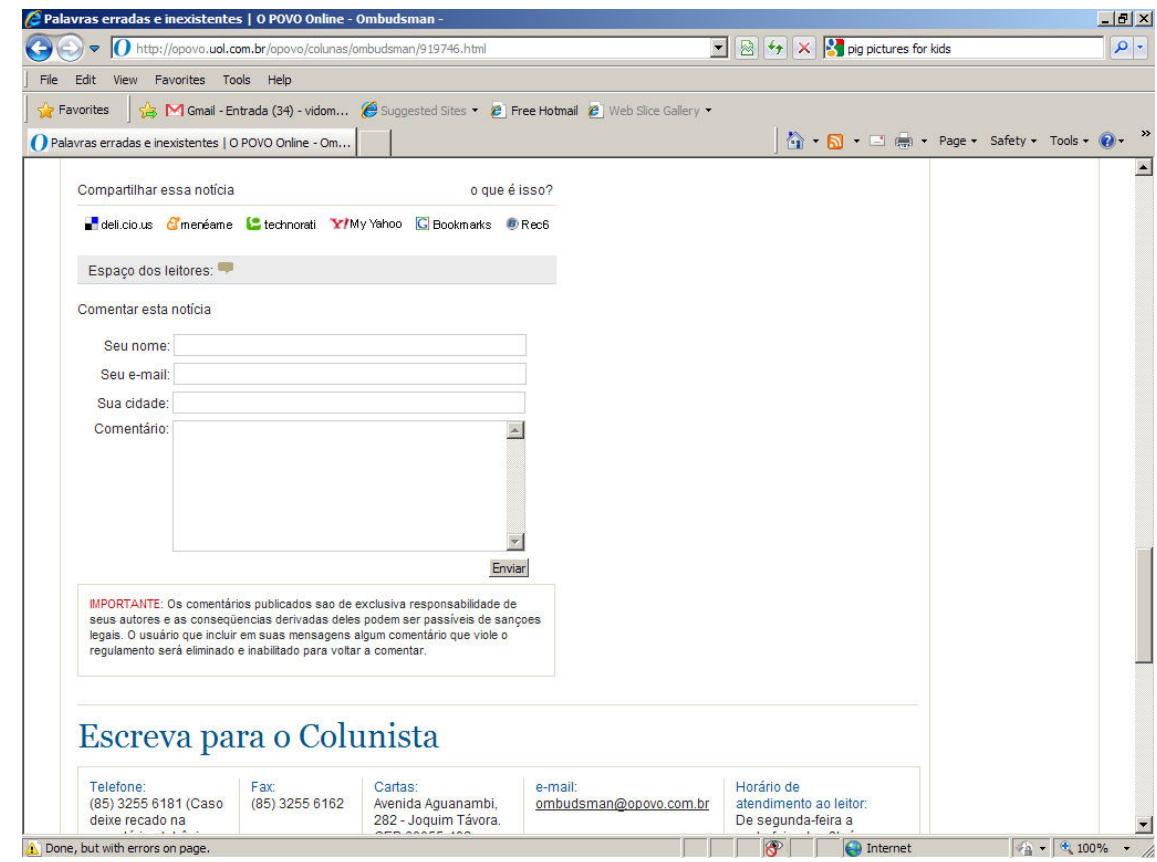

FIGURA 6. Página eletrônica da coluna de Faheina (final)

\section{APRESENTAÇÃO DOS RESULTADOS}

Nesta seção, inicialmente, investigamos os processos de mobilização de outros dizentes encontrados no corpus. Em seguida, verificamos as estratégias de construção simbólica utilizadas pelos dois ombudsman. Por fim, com base nessas duas primeiras 
etapas de análise, realizam-se a terceira e a quarta etapas: verificar que identidade o ombudsman constrói, mediante sua coluna, para si e para os leitores; verificar quais são os modos de operação da ideologia mobilizados para manutenção da hegemonia do jornal em relação aos leitores.

\subsection{Mobilização de outros dizentes}

Faheina e Silva constroem suas colunas de maneira bastante diversa. Além das diferenças na organização textual (Silva segmenta a coluna em várias seções, enquanto Faheina apresenta um ou dois textos), as colunas também se distinguem bastante quanto à proporção entre as falas do ombudsman e as falas citadas. Nos textos de Silva, a autoria é quase toda dele próprio; o ombudsman é econômico no uso de discurso citado. E, quando cita, prefere o uso do discurso indireto. É relativamente comum que os dizentes, especialmente quando se trata de leitores, não sejam identificados pelo nome. Eis alguns exemplos retirados de Silva:

Nos EUA, o editor-executivo do "New York Times", Bill Keller, em entrevista ao "Los Angeles Times", revelou que se discute internamente a conveniência de manter o "editor público" (como chamam o ombudsman) após o fim do mandato do atual, em 2010. Em resposta, o editor da "American Journalism Review" escreveu: "Este tipo de autocrítica [do ombudsman] manda mensagem poderosa ao público. Ela diz que somos suficientemente grandes para encarar os nossos erros. E diz que estamos conscientes de que devemos explicações" [...] Mas, como me disse uma leitora, quando a Redação segue a direção aqui proposta, a valia da mudança é muito grande por ser produto da força do convencimento, não da coerção ("Para quê Cassandra, Grilo, alter ego?”, FSP, 9/8/2009, grifos nossos)

Como explica Roberto DaMatta, "o que conta no futebol não é bem a treinada vontade humana, mas a sensual e caprichosa bola. Bola que simboliza a gratuidade da vida e, de quebra, representa a sorte e o azar" ("A bola corre mais que os homens", FSP, 16/8/09, grifos nossos)

Pelo menos uma leitora, que se manifestou ao ombudsman nesses termos, acha que a barreira entre publicidade e jornalismo se rompeu: "[essa entrevista]... é antijornalística, é pura propaganda" ("Para pensar a felicidade e a velhice", $F S P, 16 / 8 / 09$, grifos nossos)

Entrevistei Gustavo Escobar, do CPTEC (Centro de Previsão de Tempo e Estudos Climáticos) do Inpe (Instituto Nacional de Pesquisas Espaciais), que fornece as previsões publicadas pela Folha. Ele explica que o clima tropical ou subtropical, o da maior parte do Brasil, é o de mais difícil previsibilidade [...] É o que o leitor Eduardo Murata cobra: "Gostaria de perguntar por que apenas depois das enchentes desta semana a Folha acordou para as obras das marginais e a impermeabilização resultante?" ("Próspero e o feitiço do tempo", FSP, 13/9/09, grifos nossos)

Nesta quinta, saiu importante reportagem sobre AVC, que mereceu do leitor Octávio Pontes, neurologista, mensagem em que diz que "infelizmente a doença só tem sido abordada pela mídia quando faz 
vítimas ilustres", mas que neste caso "o tema foi abordado com isenção" e profundidade ("Seção de saúde não é supérflua", FSP, 27/9/09, grifos nossos).

Curiosamente, Silva apresenta um texto em que todas as falas são atribuídas a outros dizentes que não ele próprio. No texto "Por que tão poucos ombudsmans?" (20/9/09), a pergunta do título é respondida por oito ombudsman ou ex-ombudsman e dois outros jornalistas. Apresentam-se somente as falas dos entrevistados, identificados pelo nome e algum dado profissional, sem comentários. Não são usados verbos dicendi para introduzir as falas. Eis um exemplo:

ALBERTO DINES, precursor do ombudsman no país: "Não se meta nisso, você só vai ganhar inimigos!...” O sábio Octavio Frias de Oliveira tentava persuadir-me a não iniciar coluna de crítica de imprensa na Folha. Como sempre, Frias acertou na mosca. Nós, jornalistas, fazemos cobranças e detestamos ser cobrados. Por isso ninguém quer passar a vida brigando com colegas de profissão. Além do mais, os criticados estão sempre em cargos de chefia. ("Por que tão poucos ombudsmans?", FSP, 20/9/09)

Chama também nossa atenção em Silva um uso do chamado discurso indireto livre:

Há quem não entenda a função do ombudsman. Se ele não tem poder para impor seu pensamento à Redação e obrigá-la a agir como acha certo, qual é a sua utilidade? ("Para quê Cassandra, Grilo, alter ego?", FSP, 9/8/2009, grifos nossos)

Nesse trecho, Silva mobiliza um dizente não especificado, identificado pelo pronome quem e se apropria de sua fala, porque precisa contrapor-se a ela para elaborar sua argumentação.

Nas colunas de Faheina, a citação das falas de outros é recurso frequente e constitui a maior parte do texto. Disso resulta que a autoria de menos da metade (geralmente, bem menos) do texto de Faheina possa ser atribuída a ela própria. A ombudsman identifica com mais frequência os dizentes, sejam eles especialistas ou leitores, e usa mormente o discurso direto. A título de exemplo, apresenta-se o texto "Palavrões e frases chulas" $(1 \% / 09)$, no qual se grifaram apenas as falas atribuíveis à própria ombudsman 9 . Observe-se como a maior parte do texto é constituída por falas de outros dizentes ou citações de textos do próprio jornal. A jornalista inicia o assunto e depois, mobilizando vários dizentes, abre um espaço dialógico no qual aparecem tanto falas contrárias como favoráveis à ação do jornal: publicar frases chulas proferidas por Chorão, vocalista da Banda Charlie Brown Jr., durante um show da banda em Fortaleza.

“Convoca o público a acordar a vizinhança 'pau no c.' E ainda se sai com a definição 'Fortaleza é do c...!"”. A consoante é a inicial de palavras diferentes que os leitores entendem muito bem, principalmente os que leram a matéria da edição da última

\footnotetext{
${ }^{9}$ Obviamente, pensando em termos bakhtinianos, os discursos citados, arregimentados e enquadrados por Faheina, passam a ser também fala dela. Mas, por simplicidade de análise, consideramos aqui as citações (quer em discurso direto ou indireto) como falas alheias.
} 
segunda-feira, 17, sobre o show da banda Charlie Brown Jr. As frases são do vocalista Chorão que deu um péssimo exemplo para os jovens que prestigiaram o show no Parque do Cocó, último dia 25. A atração encerrou a série de shows gratuitos promovidos pelo Governo do Estado.

Palavras e frases de mau gosto do rapaz foram transcritas na matéria de autoria do repórter Henrique Araújo, o que desagradou a vários leitores. Como eu, muitos se sentiram agredidos com o que disse o vocalista (e O POVO publicou) que não teve o menor respeito ao público. A leitora Magnólia Almeida, por exemplo, sugeriu "uma reflexão sobre as expressões chulas ditas pelo Chorão e reproduzidas pelo repórter. "Será que é válido esse tipo de reprodução? A expressão é agressiva demais, não?”, indaga.

No show do rapaz que se definiu como "o mau exemplo que deu certo" não faltaram garrafas de cerveja cortando os ares, brigas e a histeria do público, segundo foi dito na matéria. "O que o repórter descreveu serviu para a gente conhecer quem é esse Chorão e sua banda. O que ele passa para o seu público. Veio aqui para debochar e dizer o que tem vontade", disse outro leitor.

Mas com ele não concordou, por exemplo, a professora e jornalista Adísia Sá que ligou no dia em que a matéria foi publicada. A ombudsman emérita ficou indignada com o que foi divulgado "como jornalista, leitora e integrante do Conselho Editorial do O POVO", frisou. Lamentou ainda a publicação das expressões chulas, o diretor institucional do O POVO, Plínio Bortolotti (ex-ombudsman) que também comenta, internamente, as matérias publicadas no jornal. "Os leitores do O POVO merecem um texto decente, a vizinhança tem o direito de, no mínimo, não ser xingada”, disse em seu comentário do dia.

Na mesma página da edição de segunda-feira, uma matéria sobre a apresentação da cantora Ivete Sangalo mostrou que ela também não tem papas na língua e diz o que tem vontade. "A musa da avenida" como dizia o título da notícia desafiou o público do Fortal, com a seguinte frase: "Quem não dançar vai pegar uma coceira na virilha" e anunciando uma música que gravou com uma banda de forró se saiu com essa: "Agora é hora de dançar um mela-cueca".

Atendendo ao pedido da ombudsman, o repórter Henrique Araújo e o editor-assistente do Núcleo de Cultura \& Entretenimento, Magela Lima (editor das matérias), enviaram explicações por e-mail. "Confesso que reagi aos palavrões do Chorão com o mesmo posicionamento do leitor que você encaminhou no comentário. Penso que o Henrique flagrou bem uma rebeldia enlatada que a banda parece vender. A meu ver, acertamos, por mais que possa parecer chocante para alguns leitores. Quanto às expressões da Ivete são parte do lado cômico da cantora. Ela não fala aquilo de forma vulgar, fala de forma jocosa mesmo", disse Magela e pediu "desculpas por possíveis contratempos".

Em seu e-mail, o repórter Henrique Araújo disse: "Concordaria com tudo que foi dito se, realmente, a minha intenção fosse reproduzir acriticamente o discurso do vocalista Chorão. Mas não foi o que 
aconteceu. Há ironia nas passagens em negrito (da matéria). Lamento que a intenção do texto, que era exatamente confrontar a atitude falsamente rebelde de Chorão com o contexto, tenha passado totalmente despercebida. Em nenhum momento "comprei" o discurso desarticulado da banda. Em nenhum momento reproduzi meramente as palavras do vocalista. Em nenhum momento quis desrespeitar a vizinhança. De qualquer forma, terei mais cuidado com esse tipo de material. Afinal, a leitura não é algo fechado. Interpretações erradas sempre podem surgir".

Sobre a divulgação dos palavrões e frases chulas, pedi a opinião do professor, jornalista e escritor, Gilmar de Carvalho. Vejam o que ele disse: "O mundo do show-bizz é o mundo do estresse. Também um mundo dos estados alterados de consciência. Público e artistas bebem e usam drogas. Não dá para imaginar que Chorão ou Ivete teorizem sobre a histeria coletiva, falem sobre indústria cultural ou a melancolia de Saturno. O que eles dizem são palavras de ordem, comandos, provocações. Eles estão numa batalha, num campo minado. Vai ao show quem quer e quem vai sabe o que rola por lá. Cabe ao jornal dizer o que aconteceu. SEM CENSURAS. Pelo amor de Deus, não é hora para melindres. Esta linguagem é corrente. A censura me lembra a entrevista da Leila Diniz, ao Pasquim, cheia de asteriscos. Vivemos outro tempo, de liberdade, inclusive para vermos shows idiotas e sermos agredidos de graça pelo lixo da indústria do entretenimento".

Na coluna do sábado seguinte, $8 / 8 / 2009$, no texto "O show, a ombudsman e o debate", Faheina continua mobilizando vários outros dizentes, desta vez para comentar opiniões expressas na coluna anterior.

É importante observar que a mobilização tão profusa de textos de autoria alheia não implica que Faheina faça meramente uma colagem e se afaste do espaço discursivo criado. Ao contrário, dele participa ativamente, tanto pelo recorte das falas, quanto pelo uso de alguns verbos dicendi bastante expressivos:

Lamentou ainda a publicação das expressões chulas, o diretor institucional do O POVO, Plínio Bortolotti [...] [Ivete Sangalo] se saiu com essa: "Agora é hora de dançar um mela-cueca" ("Palavrões e frases chulas", $O P, 1 / 8 / 2009$, grifos nossos)

Colaboradores reclamam dos cortes nos artigos e nas cartas enviadas à editoria de Opinião, além da demora na publicação dos textos. Um deles é Américo Souza, que se queixa de cortes no artigo intitulado "Uma vez mais a cultura do espetáculo" ("Cartas e artigos", $O P$, $15 / 8 / 2009$, grifos nossos)

"O pior é que a mesma notícia sobre o concurso do IBGE estava repetida na página 10 do mesmo caderno", reclamou ("Cadê a notícia"?, $O P, 12 / 9 / 2009$, grifo nosso).

Além disso, Faheina também comenta as falas que reproduz:

Neste ponto, o leitor tem razão ("O show, a ombudsman e o debate", $O P, 8 / 8 / 2009$, grifo nosso) 
"Tem de ter um revisor aí, né? disse o leitor". Reforço a reclamação ("A troca dos escudos e a indignação da torcida", $O P, 15 / 8 / 2009$, grifo nosso)

Ele tem razão, pois o editor deveria avisá-lo sobre as modificações ("Cartas e artigos", $O P, 15 / 8 / 2009$, grifo nosso)

Concordo com o jornalista quando ele diz que a construção da legenda deveria ser em conjunto ("Descuido com as legendas", $O P, 29 / 8 / 2009$, grifo nosso)

\subsection{Estratégias de construção simbólica}

Silva e Faheina usam estratégias de construção simbólica bastante diferentes, tanto em variedade quanto em quantidade. Encontram-se, nas colunas de Silva que analisamos, estratégias de racionalização e universalização, narrativização, eufemização, tropos, construção de oponente/interlocutor e nominalização/apassivação. Já nas colunas de Faheina, as estratégias de construção simbólica são bem menos frequentes e pouco variadas. As mais frequentes são as estratégias de unificação, padronização e simbolização da unidade.

\subsubsection{Racionalização e universalização}

Estratégias de racionalização e universalização não aparecem nas colunas de Faheina. Nos textos de Silva, essas estratégias aparecem, mas não em abundância. No texto "A internet a serviço do jornalismo" (FSP, 2/8/09), observa-se um processo de racionalização e de universalização, mediante o qual fatos relativos à internet no EUA são apresentados como tendo validade para o jornalismo em geral, inclusive o brasileiro. Silva cita inovações realizadas por jornais americanos relativamente ao oferecimento de serviços baseados na internet. De todos os exemplos particulares apresentados, Silva deduz uma afirmação de caráter universal: [...] uma ligação orgânica entre jornalismo e acompanhamento de políticas públicas pode ser um caminho promissor.

Também se observa uma estratégia de racionalização no texto "Para quê Cassandra, Grilo, alter ego?” (FSP, 9/8/09). Diante da constatação inevitável de que a redação geralmente ignora os conselhos do ombudsman, Silva argumenta que quando as sugestões são aceitas, o resultado é compensador: Mas, como me disse uma leitora, quando a Redação segue a direção aqui proposta, a valia da mudança é muito grande por ser produto da força do convencimento, não da coerção. Seguindo com o raciocínio, Silva argumenta que, mesmo quando o ombudsman não é ouvido, sua função tem grande importância. Para isso, compara o papel do ombudsman ao mito de Cassandra e ao trabalho de alter ego da personagem Grilo Falante, de Pinóquio e finaliza o texto reafirmando o papel de ombudsman como uma espécie de consciência do jornal:

Seu objetivo deve ser tentar satisfazer a necessidades específicas de todos os leitores, não a todas as necessidades de leitores específicos. Muitos ficam insatisfeitos. Principalmente os que anseiam por alterações nas grandes linhas editoriais. É natural. Mas Cassandras, 
grilos e alter egos só têm valor quando são atendidos? ("Para quê Cassandra, Grilo, alter ego?", FSP, 9/8/09)

Essas estratégias de racionalização estão presentes em vários outros textos de Silva, principalmente como forma de amenizar as críticas que ele próprio ou outros fazem ao jornal. Eis dois exemplos. No texto "Quando Deus entra na pauta", por exemplo, Silva justifica eventuais atitudes tendenciosas da Folha pela dificuldade de parecer isento quando o tema é religião:

A dificuldade de cobrir com isenção e exatidão assuntos referentes a religiões é clara e notável. Superá-la exige investimento não desprezível de estudo e dedicação. Não só a sensibilidade do público neste terreno é enorme como é imensa a complexidade das diferenças entre as igrejas e no interior de cada uma [...]. ("Quando Deus entra na pauta", $F S P, 23 / 8 / 09$ )

No texto "Próspero e o feitiço do tempo", as falhas da Folha quanto à previsão do tempo são atribuídas à imprevisibilidade do nosso clima e a limitações dos serviços de previsão:

Entrevistei Gustavo Escobar, do CPTEC (Centro de Previsão de Tempo e Estudos Climáticos) do Inpe (Instituto Nacional de Pesquisas Espaciais), que fornece as previsões publicadas pela Folha. Ele explica que o clima tropical ou subtropical, o da maior parte do Brasil, é o de mais difícil previsibilidade, e que limitações tecnológicas no país, como o pequeno número de radares de que dispõem os institutos, impedem maior precisão para antecipar a intensidade de eventos climáticos severos, como as exatas quantidades de chuva ou velocidade de ventos. ("Próspero e o feitiço do tempo", FSP, 13/9/09)

\subsubsection{Narrativização}

Em Silva, encontramos um exemplo da estratégia de narrativização. No texto "Para que Cassandra, Grilo, alter ego", o mito grego de Cassandra e a personagem Grilo Falante (personagem de Pinóquio) são usados para legitimar a profissão de ombudsman. Como Cassandra e Grilo, o ombudsman está condenado a, muitas vezes, ter os seus conselhos ignorados. Mas isso não tira, segundo Silva, o valor da profíssão:

Duas analogias ao seu trabalho me ocorrem: a do mito grego de Cassandra e a do personagem Grilo Falante, do clássico da literatura infantil "As Aventuras de Pinóquio", de Carlo Collodi, [...]. Cassandra recebeu de Apolo o dom de prever acontecimentos com a condição de que ninguém acreditasse nela. $\mathrm{O}$ Grilo faz o papel de consciência crítica, alter ego, do boneco que vira gente. Ambos suscitam dúvidas. Como o ombudsman também deve fazer, tanto entre jornalistas quanto entre leitores. [...] Muitos ficam insatisfeitos. Principalmente os que anseiam por alterações nas grandes linhas editoriais. É natural. Mas Cassandras, grilos e alter egos só têm valor quando são atendidos? ("Para que Cassandra, Grilo, alter ego", FSP, 9/8/09) 


\subsubsection{Eufemização}

O papel do ombudsman é valorado positivamente por Silva, especialmente na matéria "Para quê Cassandra, Grilo, alter ego?" (9/8/09), publicada em comemoração aos 20 anos do cargo de ombudsman na Folha de S. Paulo. Essa valorização do ombudsman dá-se tanto por escolhas lexicais que enaltecem seu papel, como pela estratégia de racionalização, discutida anteriormente. Observem-se os exemplos:

Mesmo que nunca a Redação acatasse as opiniões do ombudsman, ainda assim ele teria um papel importante; Num mundo em que as certezas têm feito tanto mal às pessoas, espalhar dúvidas pode ser uma bênção; E contribui para a reflexão sobre o papel do jornalismo na sociedade; Seu objetivo deve ser tentar satisfazer a necessidades específicas de todos os leitores. ("Para que Cassandra, Grilo, alter ego", FSP, 9/8/09, grifos nossos)

O jornal também recebe uma valoração positiva de Silva, frequentemente para compensar críticas negativas feitas pelo próprio ombudsman. É o que se vê, por exemplo, no texto "A bola corre mais que os homens" (FSP, 16/8/2009). Num texto que critica o jornal por abusar das estatísticas, Silva faz o seguinte elogio: Acho que a Folha acertou ao apostar num tratamento mais frio, objetivo, comprovável do que até então era basicamente cuidado com impressionismo, paixão, palpite.

Esse mesmo jogo de eufemização em contexto de crítica pode ser visto no texto de Silva "Para pensar a felicidade e a velhice" (FSP, 6/8/09), que critica o jornal por misturar jornalismo com publicidade em matéria a respeito de um sítio eletrônico mantido pelo empresário Abílio Diniz. O texto abre com Abilio Diniz é um grande empresário. Suas opiniões sobre negócios, economia, empreendedorismo, governança estão lastreadas por inegáveis êxitos nessas áreas de atividade. É interessante observar que, no período que se segue, a apresentação de atributos positivos em posição temática parece fazer com que o tom elogioso continue, mesmo quando a crítica já começou: Como filósofo, pensador, artista, investigador dos meandros da psique humana, seus atributos não são indiscutíveis a ponto de justificar o destaque e espaço dedicados aqui ao lançamento de seu site com "receitas de felicidade". No restante do texto, a crítica ao jornal não atinge Abílio Diniz.

No texto de Silva "Quando Deus entra na pauta" (FSP, 23/8/09), também se observa como a crítica ao jornal vem atenuada pela estratégia de eufemização: Depois de não dar nenhuma importância ao acordo entre Brasil e Santa Sé assinado em novembro, o jornal despertou agora quando sua ratificação é debatida na Câmara; Todas as reportagens publicadas foram corretas. $\mathrm{O}$ mesmo pode ser observado no texto "Combater sintomas não basta" (FSP, 30/8/09): Na terça-feira, com foto dramaticamente bela na primeira página, este jornal mostrou que, passados quase cem anos, na cidade brasileira de São Paulo os métodos de despejo não mudaram muito. $O$ registro da violência do despejo foi benfeito. E também é visível no texto "Seção de saúde não é supérflua" (FSP, 27/9/09): Uma das boas novidades deste jornal em 2008 foi a página diária de saúde, criada em outubro; Nesta quinta, saiu importante reportagem sobre $A V C$ [...]. Por fim, na coluna de Silva, as seções 
conjugadas "Onde a Folha foi bem..." e "...e onde foi mal" organizam-se de forma a compensar, com elogios, as críticas.

Em Faheina, a estratégia de eufemização foi também encontrada, mas com menor frequência. No texto "O show, a ombudsman e o debate" $(O P, 8 / 8 / 09)$, Faheina afirma que os palavrões de Chorão, vocalista da banda Charlie Brown Jr., não deveriam ter sido reproduzidos pelo jornal (na verdade, somente as iniciais das palavras o foram), devido à linha educativa que o jornal segue. No texto "A troca de escudos e a indignação da torcida" (OP, 15/8/09), no subtítulo "Cartas e artigos", explica-se porque as colaborações de leitores (artigos de opinião) demoram a ser publicadas. $\mathrm{O}$ período final - Assim, naturalmente, acumulam-se contribuições, sobretudo, dos artigos maiores - é de autoria dúbia - não é possível determinar se é da própria Faheina ou do editor de opinião, por ela citado. Supondo-se que a autoria do período seja atribuída a Faheina, tem-se eufemização. No texto "Tolerância zero', a boa notícia" (OP, 22/8/09), Faheina classifica como "decisão acertada" e "boa ideia" a medida adotada pelo portal $O$ Povo Online e pela rádio $O$ Povo/CBN de acolher denúncias de desrespeito à Lei do Silêncio, destinada a combater a poluição sonora em Fortaleza. Por fim, no texto "Descuido com as legendas" (OP, 29/8/09), após citar vários exemplos de legendas mal elaboradas em fotos publicadas pelo jornal, Faheina elogia a legenda de uma foto publicada na seção Política.

\subsubsection{Tropos}

O tropo mais frequente nos textos de Silva é a metonímia. Ao invés de referir-se aos profissionais do jornal, Silva usa os termos "Redação", "Folha" e, mais comumente, "jornal", como se pode ver nos seguintes exemplos:

[...] jornal teima em usar a denominação antiga e inapropriada (“...e onde foi mal", FSP, 2/8/09, grifo nosso)

Se ele não tem poder para impor seu pensamento à Redação [...] ("Para quê Cassandra, Grilo, alter ego?", FSP, 9/8/09, grifo nosso)

Jornal cobre acanhadamente a inaceitável censura prévia imposta pela Justiça a "O Estado de S. Paulo" (“...e onde foi mal, FSP, 9/8/09, grifo nosso)"

[...] o jornal avalizou suas opiniões sobre os mistérios da alma como importantes para a sociedade ("Para pensar a felicidade e a velhice", FSP, 16/8/09, grifo nosso)

Mas o jornal deixou de abordar aspectos fundamentais [...] ("Quando Deus entra na pauta", $F S P, 23 / 8 / 09$, grifo nosso)

Se isso depender da vontade editorial demonstrada até agora por este jornal, nada irá mudar ("Nada além do bate-boca", FSP, 23/8/09, grifo nosso)

Dado da pesquisa de intenção de voto subestimado pela Redação [...] (“... e onde foi mal", FSP, 23/8/09, grifo nosso)

A Folha [...] não tem conseguido dar a seu leitor visão clara sobre que interesses de que pessoas estão em jogo nem esclarecer se a tal 
reunião de fato ocorreu e qual teria sido seu conteúdo e contexto ("É difícil desvendar vespeiros", $F S P, 30 / 8 / 09$, grifo nosso)

Jornal cobre mal erros e suspensão do juiz de Cruzeiro e Palmeiras (“...e onde foi mal”, FSP, 27/9/09, grifo nosso).

Em outros momentos, Silva menciona o caderno ou usa termos gerais, como "matéria" ou "reportagem":

O fato de o escritor português Lobo Antunes estar namorando uma jornalista brasileira não justifica manchete de página, como na Ilustrada de sexta (“...e onde foi mal”, FSP, 30/8/09, grifo nosso)

Material sobre morte de Edward Kennedy na quinta não faz nenhuma referência a seu importante papel no combate às ditaduras militares na América do Sul, inclusive a do Brasil, e ao apartheid na África do Sul (“...e onde foi mal", FSP, 30/8/09, grifo nosso);

[...] tramitação de projetos no Congresso continua esquecida pela reportagem (“...e onde foi mal”, FSP, 13/9/09, grifo nosso)

Reportagens na terça e na quarta permitem interpretar que responsabilidade por ilegalidades e atrasos em obras que constam do PAC é do governo e não das empreiteiras que as realizam (“...e onde foi mal", FSP, 13/9/09, grifo nosso).

Faheina usa, com frequência bem menor, o tropo metonímia e, quando o faz, não usa o nome do jornal para ocultar o autor da matéria. Ao contrário, é prática sua incluir em suas críticas o nome do profissional responsável pela falha denunciada (ou ao menos o seu cargo), o que pode ser visto em praticamente todas as colunas. Apenas para citar alguns exemplos:

Palavras e frases de mau gosto do rapaz foram transcritas na matéria de autoria do repórter Henrique Araújo, o que desagradou a vários leitores ("Palavrões e frases chulas", $O P, 1 / 8 / 09$, grifo nosso)

Faltou cuidado do editor e diagramador na hora de revisar a página ("A troca dos escudos e a indignação da torcida", $O P, 15 / 8 / 09$, grifo nosso)

A ombudsman, mesmo solicitando, por e-mail, uma explicação da editora do Núcleo de Negócios, Neila Fontenele, não obteve resposta sobre o erro nas duas ocasiões ("Cadê a notícia", $O P, 12 / 9 / 09$, grifo nosso).

Quando o nome do profissional não é citado, Faheina cita, pelo menos, a matéria, a coluna ou o caderno onde ocorreu a falha:

$\mathrm{Na}$ edição do dia 29 de junho (Brasil, pág. 22) na matéria "Morre a primeira vítima da gripe suína no Brasil", a foto mostra três homens caminhando não se sabe onde e as costas de um outro usando o colete da Defesa Civil. Na legenda, a seguinte frase: prefeito do Rio Eduardo Paes e secretário de (da) Saúde Sérgio Cortês debatem agravamento da pandemia. Estavam era visitando um local. Não se sabe onde. ("Descuido com as legendas", $O P, 29 / 8 / 09$, grifo nosso) 
Outro erro foi a repetição de uma página no caderno de Economia. (“Informação ou desinformação?", $O P, 5 / 9 / 09$, grifo nosso)

Colaboradores reclamam dos cortes nos artigos e nas cartas enviadas à editoria de Opinião ("Cartas e artigos", $O P, 15 / 8 / 09$, grifo nosso).

\subsubsection{Construção simbólica de um oponente/interlocutor}

Observamos, nas colunas de Silva, em alguns momentos, que opera a construção simbólica se não de um inimigo, mas de um oponente, um interlocutor descorporificado a cujas opiniões o ombudsman se contrapõe. Isso é feito mediante perguntas retóricas, processos de apassivação ou nominalização, uso de pronomes com referentes vagos etc.

Por exemplo, no texto de Silva "Para quê Cassandra, Grilo, alter ego?" (FSP, 9/8/09), temos as perguntas retóricas Se ele não tem poder para impor seu pensamento à Redação e obrigá-la a agir como acha certo, qual é a sua utilidade? e É pouco?, dirigidas a um interlocutor não identificável. O mesmo ocorre no texto "A bola corre mais que os homens", onde aparecem perguntas encadeadas:

Como seria possível o São Paulo não atingir a "marca histórica" dos mil jogos, exceto se não entrasse em campo para jogar? Como seria possível considerar mais importante simplesmente acabar a partida, e não vencê-la e, em consequência, atingir o grupo dos quatro primeiros do campeonato? ("A bola corre mais que os homens", FSP, 16/8/09)

Isso também ocorre no texto "Combater sintomas não basta" ( $F S P, 30 / 8 / 09)$, que traz as perguntas encadeadas Os desabrigados já estão acomodados? Não há outras histórias pessoais relevantes a serem contadas ao leitor? Nada a ser dito sobre o problema do deficit habitacional de São Paulo. Assim como no texto "Jornalistas nas redes sociais", onde também aparecem perguntas encadeadas:

Se, por exemplo, um jornalista que cuida de política veicula em seu blog opiniões apaixonadamente pró ou contra um partido ou pessoa pública, de que modo o leitor vai confiar na isenção do que ele reportar na Folha? Mas como exercer controle sobre o que ele diz sobre temas que não são os de que trata no jornal sem interferir na sua liberdade de expressão? (“Jornalistas nas redes sociais", FSP, 13/9/09)

Nas colunas de Silva analisadas, essa mesma estratégia de dirigir perguntas retóricas a um locutor não identificável aparece por duas vezes, na pequena seção chamada "Prómemória": No dia 2/8/09, Silva pergunta Como anda o caso da brasileira que alegou ter sido agredida por neonazistas na Suiça? No dia 13/9/09, a seção traz as perguntas encadeadas: A crise da Receita Federal acabou? A reunião entre a ministra Dilma Roussef e a ex-chefe da Receita Lina Vieira ocorreu ou não? ("Pró-Memória", FSP, 13/9/09). Essas perguntas provocam um efeito de cobrança, mas este é parcialmente esvaziado pelo apagamento do interlocutor. Apesar de se poder prever, nesse caso, que os interlocutores visados são os redatores do jornal, o efeito obtido é diferente do que se tivéssemos antes da pergunta algo como "Pergunto à redação:". 
No texto de Silva "A internet a serviço do jornalismo" (FSP, 2/8/09), o pronome "quem" aparece experienciador do verbo enxergar (Há quem enxergue na internet um inimigo do jornalismo) e da nominalização do verbo "errar" (É um erro conceitual $e$ estratégico). A mesma estratégia de construção de um oponente descorporificado é repetida no texto "Para quê Cassandra, Grilo, alter ego?" (FSP, 9/8/09): Há quem não entenda a função do ombudsman

Nas colunas de Faheina analisadas, essa estratégia de construção simbólica de oponente/interlocutor não foi encontrada. Faheina dialoga com interlocutores reais, sejam eles leitores, sejam especialistas ou, mais comumente, colegas do jornal:

Atendendo ao pedido da ombudsman, o repórter Henrique Araújo e o editor-assistente do Núcleo de Cultura \& Entretenimento, Magela Lima (editor das matérias), enviaram explicações por e-mail [...] Sobre a divulgação dos palavrões e frases chulas, pedi a opinião do professor, jornalista e escritor, Gilmar de Carvalho ("Palavrões e frases chulas", $O P, 1 / 8 / 09$ )

Perguntei ao editor-adjunto Rafael Luís o que ocorrera e ele lembrou que tinha sido uma situação desgastante, que acabara atingindo toda a equipe. ("A troca dos escudos e a indignação da torcida", $O P$, $15 / 8 / 09)$

Concordo com o jornalista [Daniel Zimmermann] quando ele diz que a construção da legenda deveria ser em conjunto (editor, repórter e repórter-fotográfico) ("Descuido com as legendas", $O P, 29 / 8 / 09$ )

A ombudsman, mesmo solicitando, por e-mail , uma explicação da editora do Núcleo de Negócios, Neila Fontenele, não obteve resposta sobre o erro nas duas ocasiões ("Cadê a notícia?", $O P, 12 / 9 / 09$ ).

\subsubsection{Nominalização/Apassivação}

Os processos de apassivação e nominalização são frequentes nas colunas de Silva. No texto "Para quê Cassandra, Grilo, alter ego?" (FSP, 9/8/09) aparecem as construções passivas teme-se que seja espécie em risco de extinção e ver minhas sugestões e linha de raciocínio ignoradas. No texto "A bola corre mais que os homens" (FSP, 16/8/09), o verbo "inverter" é nominalizado em A meu ver, a frase simboliza uma inversão de valores jornalísticos. No mesmo texto, o verbo "considerar" é apresentado numa forma que não requer explicitação do sujeito, o infinitivo: considerar o que é mais é mais interessante, mas complementar [...] mais importante que o fundamental (o fato, $o$ acontecimento). No texto "Para pensar a felicidade e a velhice" (FSP, 16/8/09), o verbo "dedicar" aparece apassivado em seus atributos não são indiscutíveis a ponto de justificar o destaque e espaço dedicados aqui ao lançamento de seu site com "receitas de felicidade". No texto "Quando Deus entra na pauta" (FSP, 23/8/09), o verbo "acusar" vem nominalizado em Mas quando temas religiosos são enfocados com mais constância, como agora, surgem acusações de que ela favorece ou persegue esta ou aquela igreja. Na seção “...e onde foi mal”, do dia 6/9/09, aparecem duas construções passivas em Outra vez violência urbana é tratada como caso policial fortuito e não se discutem suas possíveis causas estruturais, seguidas de uma nominalização: Destaque excessivo a críticas do presidente Lula aos adversários no lançamento do pré-sal infla 
o reducionismo do tema à guerra partidária. No texto "Combater sintomas não basta" (FSP, 30/8/09), o verbo "tratar" também aparece apassivado: Este é mais um caso decorrente de enfermidades sociais graves, tratado como se fosse episódio isolado.

Nas colunas de Faheina analisadas, as estratégias de apassivação e nominalização para ocultamento de agente não foram encontradas. Como já mencionado anteriormente, Faheina tende a identificar mais diretamente as pessoas a quem suas críticas são dirigidas.

\subsubsection{Padronização/simbolização da unidade}

A única estratégia encontrada em Faheina e não em Silva é a padronização e construção de unidade. Mas deve-se ressaltar que a unidade proposta não é com o jornal como força hegemônica. É antes uma unidade entre a ombudsman e os leitores:

Como eu, muitos se sentiram agredidos com o que disse o vocalista (e $\mathrm{O}$ POVO publicou), que não teve o menor respeito ao público ("Palavrões e frases chulas", $O P, 1 / 8 / 09$, grifo nosso)

Nada poderia agradar mais a quem mora perto de casas de shows, clubes, bares e outros estabelecimentos que provocam barulho do que notícias sobre a físcalização e punição dos que desrespeitam a Lei do Silêncio. E foi a divulgação das medidas que estão sendo tomadas pela Secretaria Municipal do Meio Ambiente e Controle Urbano (Semam) para combater a poluição sonora na Cidade que tem recebido muitos elogios e apoio dos leitores do O POVO [...] Acho importante reforçar aqui essa campanha. É um dever de todos nós contribuirmos para acabar com qualquer tipo de poluição (" 'Tolerância zero', a boa notícia", $O P, 22 / 8 / 09$, grifos nossos)

Peço licença ao leitor José Nilton Mariano Saraiva para usar o título do seu e-mail enviado na última segunda-feira. Não foi o único. Outros leitores fizeram o mesmo, deixaram recados na secretária eletrônica e ligaram para reclamar do erro no GOL! ("Informação ou desinformação", $O P, 5 / 9 / 09$, grifo nosso)

A manchete do O POVO da última segunda-feira, 14, gerou discussão na empresa, entre os leitores e até em sala de aula. (" 'Por que' ou 'Porque' “, $O P, 19 / 9 / 09$, grifo nosso).

\subsection{Construção de identidades}

Observando a proporção entre a fala de Silva e a dos dizentes mobilizados por ele, vemos que ele cria em suas colunas um espaço discursivo que é dominado pela sua voz. Há uma forte tendência a um monologismo, no qual as opiniões do próprio ombudsman parecem ocupar quase todo o espaço físico do papel e o espaço discursivo. Por outro lado, nas colunas de Faheina, pela profusa mobilização de outros dizentes, a voz da ombudsman cede espaço a outras vozes. Assim, o espaço discursivo se torna amplamente dialógico. 
Com relação ao uso das estratégias de construção simbólica, vê-se que Silva as mobiliza sempre em defesa do jornal ou da atividade do ombudsman. Mediante racionalização, universalização e narrativização, ele ameniza eventuais críticas ao jornal e busca legitimar a função que exerce como ombudsman. Utilizando a eufemização, valora positivamente tanto o jornal como o fazer do ombudsman. A metonímia e os processos de nominalização são usados por Silva para evitar que as críticas ganhem um tom pessoal, atingindo os autores das matérias. Importa apresentar o jornal como um bloco coeso e não os profissionais isolados. Por fim, a construção simbólica de um oponente permite que o ombudsman exerça a crítica - que é o que se espera de alguém em sua função - mas sem dirigi-la a um oponente específico.

Por outro lado, Faheina lança mão das estratégias de construção simbólica com parcimônia. Mediante eufemização, defende o jornal em alguns momentos, mas nunca a função de ombudsman. Por outro lado, a metonímia, pouco usada, cede lugar à identificação clara do profissional a quem a crítica é dirigida. Da mesma forma, em vez de construir um oponente simbólico, como faz Silva, Faheina identifica claramente a quem dirige suas críticas. Por fim, ao usar a estratégia de padronização/construção da unidade, Faheina não busca criar uma unidade em torno do jornal, mas antes uma unidade entre a própria ombudsman e os leitores.

Portanto, Silva e Faheina constroem identidades bastante diversas como ombudsman . Silva apresenta-se ao leitor como alguém que discute fatos gerais do jornalismo e do próprio fazer do ombudsman. Um resumo das matérias principais das colunas deixa isso bem claro: "A internet a serviço do jornalismo" (FSP, 2/8/09) defende que a internet não é um inimigo do jornalismo, mas um fator de renovação; "Para quê Cassandra, Grilo, alter ego?" (FSP, 9/8/09) discute o papel do ombudsman; "A bola corre mais que os homens" (FSP, 16/8/09) critica o abuso de estatísticas no futebol; "Quando Deus entra na pauta" (FSP, 23/8/09) aborda as dificuldades do jornal para tratar de temas relativos à religião; "É difícil desvendar vespeiros" $(F S P, 30 / 8 / 09)$ discute, a partir de eventos recentes envolvendo membros do governo e políticos, a dificuldade de cobrir assuntos relacionados a política; "Jornalismo e política ambiental" $(F S P, 6 / 9 / 09)$ trata das relações entre o jornalismo e a questão ambiental; "Próspero e o feitiço do tempo" (FSP, 13/9/09) aborda o papel da imprensa na cobrança de atitudes dos poderes públicos para minimização das consequências dos desastres causados por fatores climáticos; "Por que tão poucos ombudsmans?" (FSP, 20/9/09) apresenta um painel com a opinião de alguns ombudsman e outros profissionais do jornalismo a respeito do exercício da função de ombudsman; "Astronauta faz fiasco na Lua" ( FSP , 27/9/09) critica o uso exagerado e inadequado da palavra fiasco pela Folha de S. Paulo.

Silva evita críticas muito incisivas ao jornal e, especialmente, aos colegas de trabalho. A crítica mais contundente encontrada no corpus está na fala de uma leitora:

Pelo menos uma leitora, que se manifestou ao ombudsman nesses termos, acha que a barreira entre publicidade e jornalismo se rompeu: "[essa entrevista]... é antijornalística, é pura propaganda" ("Para pensar a felicidade e a velhice", $F S P, 16 / 8 / 09$ ). 
Parece que Silva deseja distanciar-se discursivamente da parte mais agressiva da fala, que aparece em discurso direto. $\mathrm{O}$ fato de ele não comentá-la reforça essa hipótese.

Chama ainda nossa atenção, nas colunas de Silva, o fato de ele raramente usar a primeira pessoa. Isso ocorre apenas sete vezes no corpus deste estudo:

Não posso negar que experimente frustração vez ou outra ao ver minhas sugestões e linha de raciocínio ignoradas. [...] É pouco? Não acho ("Para quê Cassandra, Grilo, alter ego?", FSP, 9/8/09, grifos nossos)

A meu ver, a frase simboliza uma inversão de valores jornalísticos que vem se firmando na cobertura de esportes da Folha há muitos anos [...] Os exemplos são inúmeros. Vou citar só um ("A bola corre mais que os homens", FSP, 16/8/09, grifos nossos)

Quando eu defendi tese de mestrado sobre meios de comunicação de massa e meio ambiente, 33 anos atrás, o panorama era muito diverso. ("Jornalismo e política ambiental", $F S P, 6 / 9 / 09$, grifo nosso)

Entrevistei Gustavo Escobar, do CPTEC (Centro de Previsão de Tempo e Estudos Climáticos) do Inpe [...], que fornece as previsões publicadas pela Folha ("Próspero e o feitiço do tempo", FSP, 13/9/09, grifo nosso)

Parece-me difícil contestar o direito de o jornal, que paga seus profissionais para apurarem informações numa determinada área, requerer exclusividade daquilo que averiguam ("Jornalistas nas redes sociais", FSP, 13/9/09, grifo nosso).

O uso quase que exclusivo da terceira pessoa confere ao texto de Silva um tom de objetividade e impessoalidade, de um menor comprometimento com o dito.

Ao contrário de Silva, que prefere discutir temas mais amplos do jornalismo, Faheina dedica-se especialmente a questões comezinhas. O resumo dos seus textos evidencia isso: "Palavrões e frases chulas" $(O P, 1 / 8 / 09)$ trata do show da banda Charlie Brown Jr. e da publicação de palavrões proferidos pelo líder da banda, Chorão; "O show, a ombudsman e o debate" $(O P, 8 / 8 / 09)$ dá continuidade ao tema anterior; "A troca dos escudos e a indignação da torcida" $(O P, 15 / 8 / 09)$ aborda uma confusão cometida pelo jornal, que trocou os escudos de dois times de futebol; "Cartas e artigos" (OP, 15/8/09) trata das reclamações de leitores pela demora do jornal em publicar seus textos; "“Tolerância zero', a boa notícia" e "Mapa no portal" $(O P, 22 / 8 / 09)$ discutem a chamada Lei do Silêncio, destinada a combater a poluição sonora em Fortaleza; "Descuido com as legendas" (OP, 29/8/09) trata das legendas de fotos no jornal; "Informação ou desinformação?" $(O P, 5 / 9 / 09)$ critica o jornal O Povo por erros cometidos ao divulgar a classificação dos times no campeonato brasileiro de futebol; "Página republicada" $(O P, 5 / 9 / 09)$ critica o jornal por republicar uma página por engano; "Cadê a notícia" $(O P, 12 / 9 / 09)$ também faz críticas ao jornal, desta vez por publicar uma manchete na primeira página e não publicar a notícia correspondente; "Outras repetições" $(O P, 12 / 9 / 09)$ trata de repetições e de notícias com informações conflituosas; "Por que' ou 'Por que?"” $(O P, 19 / 9 / 09)$ trata do uso do ponto de interrogação no título de uma reportagem; "O Editorial" $(O P, 19 / 9 / 09)$ traz uma polêmica entre leitores e editor pelo fato de este ter expressado a mesma opinião em 
sua coluna e no editorial; "O ato simbólico dos vereadores" e "Justificativa" $(O P$, 26/9/09) tratam do destaque dado pelo jornal ao fato de alguns vereadores terem ido ao trabalho de bicicleta.

Também ao contrário de Silva, Faheina faz críticas contundentes ao jornal e aos colegas, que, em geral, são claramente identificados pelo nome e/ou pelo cargo, como se pode ver nestes exemplos:

Torcedores do Ceará, felizes com a vitória do Vozão diante do Atlético de Goiás, pela série B do Campeonato Brasileiro, encontram um erro grotesco na página 14 do O POVO onde foi publicada a matéria do jogo, na edição de domingo passado [...] Faltou cuidado do editor e diagramador na hora de revisar a página. Aliás, acredito que a página nem foi revisada, porque não se admite a troca de símbolos de times cearenses rivais como Fortaleza e Ceará de formatos e cores tão diferentes ("A troca dos escudos e a indignação da torcida", OP, 8/8/09, grifo nosso)

Não é a primeira vez que escrevo sobre o assunto nesta coluna. Já tinha chamado atenção, em março passado, para as legendas publicadas no O POVO que não cumprem suas funções. Observando, nos últimos meses, vejo que muitas continuam sem seguir a linha correta - com frases curtas e que incluam informações sobre o acontecimento. Encontramos muitas informações que destoam da fotografia, sem contar os erros ("Descuido com as legendas", $O P$, 29/8/09, grifos nossos)

$\mathrm{Na}$ segunda-feira passada, a explicação do Erramos era de que ocorreram problemas técnicos. Mas não disse que problemas foram esses. ("Página republicada", $O P, 5 / 9 / 09$, grifo nosso)

A ombudsman, mesmo solicitando, por e-mail , uma explicação da editora do Núcleo de Negócios, Neila Fontenele, não obteve resposta sobre o erro nas duas ocasiões ("Cadê a notícia?", $O P, 12 / 9 / 09$, grifo nosso)

Mesmo com tamanha justificativa, continuo achando que O POVO exagerou na divulgação desse ato simbólico dos vereadores ("Justificativa", $O P, 26 / 9 / 09$, grifo nosso)

E, em contraste com a relativa impessoalidade que marca as colunas de Silva, o texto de Faheina é marcado por profunda pessoalidade e comprometimento com o dito. É frequente o uso da primeira pessoa e a avaliação das falas de outros dizentes. Em pelo menos uma das colunas, Faheina se identifica com os leitores: Como eu, muitos se sentiram agredidos com o que disse o vocalista (e O POVO publicou) que não teve o menor respeito ao público ("Palavrões e frases chulas", $O P, 1 / 8 / 09$ ). O uso de verbos dicendi mais expressivos também provoca um efeito de maior presença da ombudsman no espaço discursivo da coluna.

A impressão geral que fica, então, é que Silva cria para si próprio a identidade de um representante do jornalismo e, mais especificamente, do jornal Folha de S. Paulo. Boa parte das críticas que faz ao jornal originam-se muito mais das suas convicções como 
jornalista do que de seu contato com os leitores. Prova disso é que em apenas seis casos os dizentes mobilizados por Silva são leitores:

Pelo menos uma leitora, que se manifestou ao ombudsman nesses termos, acha que a barreira entre publicidade e jornalismo se rompeu: "[essa entrevista]... é antijornalística, é pura propaganda" ("Para pensar a felicidade e a velhice", FSP, 16/8/09, grifo nosso)

Isso teria ajudado a evitar a percepção de alguns leitores de que a edição permitiu confundir a Iurd com as demais ("Quando Deus entra na pauta", $F S P, 23 / 8 / 09$, grifo nosso)

Leitores se queixaram da previsão meteorológica publicada pela Folha no dia [...] É o que o leitor Eduardo Murata cobra: "Gostaria de perguntar por que apenas depois das enchentes desta semana a Folha acordou para as obras das marginais e a impermeabilização resultante?" ("Próspero e o feitiço do tempo", FSP, 13/9/09, grifos nossos)

Na Olimpíada de Pequim, o leitor Andrei Guilherme Lopes reagiu quando leu no jornal que Jardel Gregório tinha sido um fiasco no salto triplo: "Um atleta que fica em sexto na maior competição esportiva do planeta é um fiasco?" (“Astronauta faz fiasco na Lua”, FSP, 27/9/09, grifo nosso)

Nesta quinta, saiu importante reportagem sobre AVC, que mereceu do leitor Octávio Pontes, neurologista, mensagem em que diz que "infelizmente a doença só tem sido abordada pela mídia quando faz vítimas ilustres", mas que neste caso "o tema foi abordado com isenção" e profundidade ("Seção de saúde não é supérflua", $F S P$, 27/9/09, grifo nosso).

Destaque-se que em apenas um dos textos de Silva ("Próspero e o feitiço do tempo", FSP , 13/9/09), a matéria principal da coluna parece ter sido motivada por queixa ou sugestão de leitor.

Por outro lado, Faheina cria para si essencialmente uma identidade de representante dos leitores. Exceto pela matéria "Descuido com as legendas" $(O P, 29 / 8 / 08)$, todas as demais originam-se de queixas ou sugestões de leitores. Mas, mesmo nessa matéria, o leitor não é perdido de vista. Num certo ponto, Faheina anuncia: Separei para os leitores exemplos [de legendas ruins] de edições recentes. Além disso, também inclui na matéria fala de leitor: Que língua será essa? É aramaico? Perguntou a leitora Francisca Leilah Ribeiro Freire.

Faheina também reproduz extensos trechos de cartas e e-mails de leitores, quase sempre mesclando discurso direto e indireto, como se pode ver nestes dois exemplos:

Outro que concorda, "na maior parte" com Gilmar, é o leitor Hermano Bezerra. Mas lembra que em eventos ao ar livre tem as pessoas que vão e as que lá estão forçadamente como os moradores da área do Cocó. "Eles são obrigados a ouvir ruídos em intensidade extremamente alta, 'arte' sem conteúdo, nem graça. E para aonde vai o direito dos moradores incomodados?". O leitor disse que pode ter fugido ao repórter a lembrança de uma olhadela para o entorno do 
Parque e ver os que provavelmente detestam aquilo ("O show, a ombudsman e o debate", $O P, 8 / 8 / 09$ )

Colaboradores reclamam dos cortes nos artigos e nas cartas enviadas à editoria de Opinião, além da demora na publicação dos textos. Um deles é Américo Souza, que se queixa de cortes no artigo intitulado "Uma vez mais a cultura do espetáculo". Ele acha que se o texto estava longo ou se alguns trechos não deviam ser publicados que o editor deixasse o artigo de fora. "O POVO tem o direito de decidir o que deve ou não constar em suas páginas, todavia, isso não lhe dá o direito de editar um texto de outrem e publicá-lo como se fosse sua opinião integral por ele assinado" ("Cartas e artigos", $O P, 15 / 8 / 09$ ).

\subsection{Manutenção de hegemonia}

Assumimos que o jornal, na relação com o leitor, constitui uma força hegemônica. Baseamos essa assunção nos seguintes fatos: 1) é o jornal quem decide o que será noticiado; 2) é o jornal quem decide sua linha editorial; 3) apesar de o conjunto dos leitores, juntamente com os anunciantes, sustentar o jornal, estes não constituem um grupo unificado, mas fragmentado.

Essa hegemonia do jornal será ameaçada caso os leitores constituam um corpo discursivamente unificado e passem a considerar o jornal como uma força antagônica ou um veículo de informação falho, pouco confiável. Daí a necessidade de o jornal mobilizar estratégias de construção simbólica para fazer operar sua ideologia, tomada aqui no sentido que lhe dá Fairclough (2001a): como significações da realidade que contribuem para criação e manutenção de relações de dominação.

No que diz respeito a sua contribuição para a hegemonia do jornal, novamente os dois ombudsman cujas colunas analisamos apresentam características bastante diferenciadas. Como vimos na seção 4.2, Silva lança mão de maior variedade de estratégias de construção simbólica e em maior número que Faheina. Visa com elas: a) mediante universalização/racionalização e narrativização, legitimar as práticas do jornalismo em geral e, mais particularmente, as práticas da Folha de S. Paulo e a função de ombudsman; b) através de eufemização e metonímia, apresentar o jornal como um todo coeso, cujas falhas eventuais são largamente compensadas pelos acertos; c) por meio da construção simbólica de um oponente/interlocutor, com quem argumenta, reafirmar os princípios do bom jornalismo; d) mediante estratégias de nominalização/apassivação, não produzir o efeito ideológico de reificação previsto por Thompson (1995), mas fazer uma crítica que identifica o erro sem denunciar quem o cometeu. No conjunto, essas estratégias operam para apresentar ao leitor o jornal Folha de S. Paulo como um organismo coeso, competente, que consegue reconhecer suas falhas, mas também seus méritos. Contribui para essa impressão de respeitabilidade do veículo, a escolha, por Silva, de um discurso mais neutro, objetivo e a preferência por temas de interesse mais universal, que dizem respeito ao jornalismo de forma mais ampla.

Por outro lado, em contraste com Silva, Faheina usa menor variedade e quantidade de estratégias de construção simbólica. Encontramos nas colunas de Faheina analisadas, 
uns poucos exemplos de eufemização quando a ombudsman elogia características ou ações do jornal $O$ Povo. Como já comentado, Faheina usa em alguns momentos a estratégia de padronização/simbolização da unidade. Visa com isso construir não um efeito ideológico de unificação entre os leitores e o jornal, mas de associação entre a ombudsman e os leitores.

\section{CONSIDERAÇÕES FINAIS}

A análise que realizamos neste estudo sugere que o gênero ombudsman pode compreender formas bastante diversas de interação. Enquanto, em sua coluna, Carlos Eduardo Lins da Silva cria para si a identidade de um ombudsman que busca tratar questões mais gerais do jornalismo e, como ele mesmo próprio coloca, servir como uma espécie de consciência para o jornal, Rita Célia Faheina constitui-se, em sua coluna, como uma representante do leitor junto ao jornal.

Ademais, Silva, mediante o uso de estratégia de construção simbólica, contribui com sua coluna para a manutenção da hegemonia do jornal frente aos leitores. Por outro lado, Faheina parece, com sua coluna, ameaçar essa hegemonia, por constituir um espaço discursivo no qual as práticas do jornal podem ser submetidas às críticas dos leitores e dela própria.

Esses dois modos de operação do gênero ombudsman podem estar relacionados ao leitor visado de cada jornal, à identidade do leitor construída pelo ombudsman. No caso da Folha de S. Paulo, o ombudsman parece supor um leitor mais intelectualizado, mais preocupado com questões que envolvem domínios de conhecimentos mais amplos, mais universalizantes da esfera jornalística. No caso de O Povo, a ombudsman parece ver seus leitores como mais presos a questões locais, mais próximas da esfera do cotidiano.

As colunas têm em comum o fato de que, de certa forma, abre-se um espaço ao ombudsman e ao leitor para o exercício da crítica ao jornal, como forma de permitir-lhe rever suas práticas. Assim, mediante a coluna de ombudsman, o jornal (no nosso caso, mais especialmente $O$ Povo) cria a impressão de que o monologismo e o autoritarismo da imprensa são quebrados. Mas a crítica possível não atinge o cerne do fazer jornalístico; não denuncia, por exemplo, a incapacidade da grande imprensa de se contrapor às classes hegemônicas da sociedade. Leitor e ombudsman opinam, tecem críticas, mas sempre sobre itens periféricos, como a má qualidade da previsão do tempo ou a relação entre internet e jornalismo. Portanto, a pluralidade no espaço discursivo criado pode ser largamente ilusória.

\section{REFERÊNCIAS}

BAKHTIN, M. Estética da criação verbal. São Paulo: Martins Fontes, 2003.

FAIRCLOUGH, N. Language and Power. New York: Longman, 1989.

. Critical Discourse Analysis: papers in the critical study of language.

London: Longman, 1995. 
Discurso e mudança social. Brasília: Editora UnB, 2001ª .

A análise crítica do discurso e a mercantilização do discurso público: as universidades. In: MAGALHÃES, C. (Org). Reflexões sobre a análise crítica do discurso. Belo Horizonte: Faculdade de Letras, UFMG, 2001b, p. 31-82.

Analysing Discourse: textual analysis for social research. London: Routledge, 2003a.

.El análisis critico del discurso como método para la investigación en ciencias sociales. In: WODAK, R., MEYER, M. Métodos de análisis crítico del discurso. Barcelona: Gedisa, 2003b, p.179-204.

FOUCAULT, M. A ordem do discurso. São Paulo: Loyola, 2003.

HALLIDAY, M. A. K. An introduction to functional grammar. London: British Library Cataloguing in Publication Data, 1985.

- Context of Situation. In: HALliDAY, M.A.K., HASAN, R. (Org). Language, context and text: aspects of language in a social-semiotic perspective. London: Oxford University Press, 1991, p. 3-28.

MAGALHÃES, I. Introdução: a análise de discurso crítica. Revista D.E.L.T.A., São Paulo, v.21, n.especial, p. 1-11, 2005.

MEURER, J. L. Gêneros textuais na análise crítica de Fairclough. In: MEURER, J.L; BONINI, A.; MOTTA-ROTH, D. (Orgs). Gêneros: teorias, métodos, debates. São Paulo: Parábola, 2005, p. 81-106.

MARCHEZAN, R. C. Diálogo. In: BRAIT, B. (Org.). Bakhtin: outros conceitoschave. São Paulo: Contexto, 2006.

RESENDE, V. M., RAMALHO, V. Análise de discurso crítica. São Paulo: Contexto, 2006.

SANTOS, N. A hora e a vez do leitor (Trechos do livro). In Canal da Imprensa.

Disponível em:

http://www.canaldaimprensa.com.br/canalant/cultura/dset/cultura2a.htm.

Acesso em 27/2/2010.

THOMPSON, J. B. Ideologia e cultura moderna. Petrópolis: Vozes, 1995. 


\section{ANEXO - REFERÊNCIAS DOS TEXTOS ANALISADOS}

Por conveniência, listamos apenas o título do texto principal de cada coluna, o dia de sua publicação e o(s) link(s) para acessá-las.

\section{Colunas de Faheina (O Povo)}

"Palavrões e frases chulas" (1/8/09) http://opovo.uol.com.br/opovo/colunas/ombudsman/898245.html

"O show, a ombudsman e o debate" (8/8/09) http://opovo.uol.com.br/opovo/colunas/ombudsman/900024.html

“A troca dos escudos e a indignação da torcida" (15/8/09) http://opovo.uol.com.br/opovo/colunas/ombudsman/901904.html

“"Tolerância zero', a boa notícia” (22/8/09) http://opovo.uol.com.br/opovo/ombudsman/celiafaheina2009/903766.html

"Descuido com as legendas" (29/8/09) http://opovo.uol.com.br/opovo/ombudsman/celiafaheina2009/905540.html

“Informação ou desinformação?” (05/9/09) http://opovo.uol.com.br/opovo/ombudsman/celiafaheina2009/907309.html

"Cadê a notícia?" (12/9/09) http://opovo.uol.com.br/opovo/ombudsman/celiafaheina2009/909186.html

“"Por que' ou 'Por que?"” (19/9/09) http://opovo.uol.com.br/opovo/ombudsman/celiafaheina2009/911044.html

"O ato simbólico dos vereadores" (26/9/09) http://opovo.uol.com.br/opovo/ombudsman/celiafaheina2009/913750.html

\section{Colunas de Silva (Folha de S. Paulo)}

"A internet a serviço do jornalismo" (2/8/09) http://www1.folha.uol.com.br/fsp/ombudsma/om0208200901.htm http://www1.folha.uol.com.br/fsp/ombudsma/om0208200902.htm http://www1.folha.uol.com.br/fsp/ombudsma/om0208200903.htm

"Para quê Cassandra, Grilo, alter ego? (9/8/09) http://www1.folha.uol.com.br/fsp/ombudsma/om0908200901.htm http://www1.folha.uol.com.br/fsp/ombudsma/om0908200902.htm

"A bola corre mais que os homens" (16/8/09) http://www1.folha.uol.com.br/fsp/ombudsma/om1608200901.htm http://www1.folha.uol.com.br/fsp/ombudsma/om1608200902.htm http://www1.folha.uol.com.br/fsp/ombudsma/om1608200903.htm 
"Quando Deus entra na pauta" (23/8/09) http://www1.folha.uol.com.br/fsp/ombudsma/om2308200901.htm http://www1.folha.uol.com.br/fsp/ombudsma/om2308200902.htm http://www1.folha.uol.com.br/fsp/ombudsma/om2308200903.htm

"É difícil desvendar vespeiros" (30/8/09) http://www1.folha.uol.com.br/fsp/ombudsma/om3008200901.htm http://www1.folha.uol.com.br/fsp/ombudsma/om3008200902.htm http://www1.folha.uol.com.br/fsp/ombudsma/om3008200903.htm

"Jornalismo e política ambiental" (6/9/09) http://www1.folha.uol.com.br/fsp/ombudsma/om0609200901.htm http://www1.folha.uol.com.br/fsp/ombudsma/om0609200902.htm http://www1.folha.uol.com.br/fsp/ombudsma/om0609200903.htm

"Próspero e o feitiço do tempo" (13/9/09) http://www1.folha.uol.com.br/fsp/ombudsma/om1309200901.htm http://www1.folha.uol.com.br/fsp/ombudsma/om1309200902.htm http://www1.folha.uol.com.br/fsp/ombudsma/om1309200903.htm

“Por que tão poucos ombudsmans?" (20/9/09) http://www1.folha.uol.com.br/fsp/ombudsma/om2009200901.htm http://www1.folha.uol.com.br/fsp/ombudsma/om2009200902.htm

"Astronauta faz fiasco na Lua" (27/9/09) http://www1.folha.uol.com.br/fsp/ombudsma/om2709200901.htm http://www1.folha.uol.com.br/fsp/ombudsma/om2709200902.htm http://www1.folha.uol.com.br/fsp/ombudsma/om2709200903.htm 